\title{
Performance of Home-Made Activated Carbon Ceramic Filter on Quality of Surface and Underground Water from Msambweni, Kwale County, Kenya
}

\author{
Geofrey Wekesa \\ School of Pure and Applied Sciences, Kenyatta University, PO BOX 1214-80100,Ukunda, Kenya
}

\begin{abstract}
About 17 million Kenyans lack access to clean water, causing fears of water-borne diseases. This is a consequence of contaminants introduced through human acts, including agricultural activities, industrialization, poor waste disposal, and poor drainage. In Msambweni, Kwale County, the scenario is not any different. The removal of contaminants in water to reach the World Health Organization and Kenya Bureau of Standards permissible qualities of clean water for human consumption is generally expensive. This is a challenge for residents of Msambweni, who $74.9 \%$ live below the poverty line. This research aimed at fabricating an activated carbonceramic (ACC) filter using locally available finely crushed clay and sawdust and test its efficiency, i.e. removal of Escherichia coli and total coliform, the effect on temperature, turbidity, total dissolved solids, dissolved oxygen, salinity, $\mathrm{pH}$, electrical conductivity, dissolved ions of $\mathrm{Na}^{+}, \mathrm{K}^{+}, \mathrm{Ca}^{2+}, \mathrm{Mg}^{2+}, \mathrm{HCO}_{3}{ }^{-}, \mathrm{Cl}^{-}$and $\mathrm{SO}_{4}{ }^{2-}$. The test was carried on three selected water sources of deep underground, hand pump, and surface water before and after filtration using the ACC filter. The physicochemical parameters were measured using an aqua read meter while the aqua genx test kit was employed for the bacteriological analysis. $\mathrm{Na}^{+}, \mathrm{K}^{+}, \mathrm{Ca}^{2+}, \mathrm{Mg}^{2+}, \mathrm{HCO}_{3}{ }^{-}, \mathrm{Cl}^{-}$and $\mathrm{SO}_{4}{ }^{2-}$ were analyzed using atomic absorption spectroscopy (AAS) and calorimetry. Statistical analysis was performed by SPSS software version 21 . The turbidity and DO were beyond the WHO recommended limits at $(30.00 \pm 1.00$ $\mathrm{NTU})$ and DO $(4.21 \pm 0.96 \mathrm{mg} / \mathrm{L})$ from the specimen drawn from hand pumps before filtration. The Mean $\pm \mathrm{SE}$ ranged from $22.72 \pm 1.15-23.24 \pm 1.22^{\circ} \mathrm{C}$ (Temperature); $4.99 \pm 0.01-30.00 \pm 1.00$ NTU (Turbidity), $51.12 \pm 31.85$ $68.62 \pm 66.93 \mathrm{mg} / \mathrm{L}$ (TDS), $4.21 \pm 0.96-7.48 \pm 0.33 \mathrm{mg} / \mathrm{L}$ (DO), 3.85 $\pm 0.78-5.17 \pm 0.56 \mathrm{mg} / \mathrm{L}$ (salinity), 7.37 $\pm 0.15-$ $7.46 \pm 0.02(\mathrm{pH})$ and $0.18 \pm 0.01-0.87 \pm 0.03 \mathrm{mg} / \mathrm{L}(\mathrm{EC})$. These levels decreased significantly after filtration of the water samples using the fabricated ACC Filter, subsequently falling within admissible limitation in line with the WHO excellence levels. Amounts of Faecal E. Coli (CFU/100 ml) and Faecal Coliforms (MPN/100 ml) before filtration ranged between $1.00 \pm 0.00-5.00 \pm 0.00$ and $12.00 \pm 00-25.00 \pm 0.00$ respectively, being higher than the WHO standards. However, the levels decreased significantly after filtration falling within permissible levels. The levels of dissolved ions $(\mathrm{mg} / \mathrm{L})$ were within WHO standards before filtration (BF). Notably, $\mathrm{Mg}^{2+}$ ranged from $1.04 \pm 0.01$ in underground water and $\mathrm{HCO}_{3}{ }^{-}$ranged $225.67+0.58$ in the surface water samples. These levels decreased to $0.35 \pm 0.01$ for $\mathrm{Mg}^{2+}$ and $30.50+0.10$ for $\mathrm{HCO}_{3}{ }^{-}$in underground and surface water samples, respectively, after filtration. The fabricated ACC Filter was found to remove Faecal E. Coli effectively and Faecal Coliforms in all water samples, improving turbidity but with minimal effect on dissolved ions in water hence recommended for use.
\end{abstract}

Keywords: Activated carbon, Ceramic filter, Surface water, Underground water, Water sampling

DOI: $10.7176 / \mathrm{JEES} / 12-1-04$

Publication date: January $31^{\text {st }} 2022$

\section{Introduction}

It is projected that by 2025 , about $40 \%$ of the world's population will face scarcity of safe drinking water (Hoekstra et al., 2012). This translates to a $10 \%$ increase in people who lack access to safe and readily available water (Hagemann et al., 2013). The dangers associated with unsafe drinking water are waterborne diseases that kill almost 5 million children and cause sickness to nearly $17 \%$ of the world's population each year (Roche et al., 2017).

In 2017, the World Health Organization (WHO) and United Nations Children's Fund (UNICEF) approximated that about $50 \%$ of illnesses in Kenya are water, sanitation, and hygiene-related. According to WHO, $94 \%$ of these ailments can be evaded by accessing safe drinking water (Hoekstra et al., 2012). These dangers are a result of bacteriological (Total coliform and Escherichia coli[E.Coli]), physicochemical parameters (temperature, turbidity, total dissolved solids, dissolved oxygen, salinity, $\mathrm{pH}$, and electrical conductivity) and dissolved ions $\left(\mathrm{Na}^{+}\right.$, $\mathrm{K}^{+}, \mathrm{Ca}^{2+}, \mathrm{Mg}^{2+}, \mathrm{HCO}_{3}^{-}, \mathrm{Cl}^{-}$and $\mathrm{SO}_{4}{ }^{2-}$ ) levels of water being beyond those recommended by the WHO (Uhuo et la., 2014).

In Kenya, $43 \%$ of the population lack pure drinking water (Mwihaki, 2018). Due to the high population in some counties, there is a lack of reliable and purified water (Guo et al., 2017). Msambweni sub-County, in Kwale county Kenya for example, has approximately $74.9 \%$ of its population faced with water scarcity (Mutuku et al., 2013). A good proportion (71\%) of the residents rely on natural water sources such as ponds, shallow wells, and 
rivers whose quality deteriorates during wet seasons. According to Mutuku et al. (2013), the remaining smaller proportion of residents obtain quality, reliable, adequate water and sanitation services from the Kwale Water and Sewerage Company (KWAWASCO), one of the Water Service Providers (WSPs). According to Ferrer Ramos (2019), it is feared that due to the rapid expansion and population growth in Kwale, the need for quality, reliable and adequate water will increase.

According to the Environmental Protection Agency (EPA), only $10 \%$ of surface water has no contaminants, though studies on the determination of water quality have shown varying results (Olago, 2018). In Kwale County, for example, both the quality and quantity of water in shallow wells in the area were generally acceptable for domestic use. (Chalala et al., 2017b). On the contrary, a study on groundwater pollution by Chepkemoi (2017) found that $13 \%$ of boreholes were contaminated with $E$. coli, compared to $30 \%$ of natural springs and $69 \%$ of open wells. Chalala et al. (2017) reported that the $\mathrm{pH}$ of surface water sources ranged from 6.5 to 8.5 with limits exceeding those of standards for conductivity, chlorides, turbidity, and Total Dissolved Solids (TDS). Magnesium, iron, sodium, and potassium nutrients were below the permissible levels for irrigation water.

Most surface water sources are contaminated with total coliforms, including $E$. coli hence not suitable for domestic use (Coleman et al., 2013). Water quality in boreholes (32\%) and wells in the county have been shown to either permanently or temporarily fail to reliably discharge good quality drinking water to the locals (Kilwake, 2016). The contaminants are introduced through high usage of fertilizer in sugar cane farming and poor waste disposal methods (Anastopoulos et al., 2017)

Water can be purified through physical, chemical, and biological processes (Bolisetty, Peydayesh \& Mezzenga, 2019), such as membrane filtration, adsorption, and boiling. Physical methods include sedimentation, screening, filtration, degasification, and equalization. Chemical processes include chlorination, ozonation, neutralization, coagulation, adsorption, and ion exchange. Biological methods include activated sludge treatment, trickling filtration, oxidation ponds, lagoons, aerobic digestion, and anaerobic digestion (Lariyah et al., 2016).

Purifying water using filtration, solar disinfection, and chlorination in removing biological contamination is expensive, hence finding limited application, especially in the rural setups (Zaman et al., 2017). Membrane filtration is costly and needs electricity to run, and its initial capital is huge hence generally unaffordable for the poor(REF). Boiling as an alternative method is more expensive due to the amount of fuel used which commonly is charcoal (Ponce-Robles et al., 2017).

Activated carbon filters have been used to address the challenges in water purification (Dong et al., 2019). The filters are small pieces of carbon, typically in granular or powdered block form, treated to be highly porous. The use of activated carbon ceramic filters effectively improves the physicochemical properties of water, removes and inactivates bacteria and bacterial indicators of disease-causing organisms (Lantagne \& Yates, 2018). These filters can be designed in the shape of a flowerpot or bucket for easy use at home.

This study aimed at providing an effective and cheaper way of purifying natural waters. It will design an alternative way of purification, which will reduce the burden of water-borne diseases caused by E. coli and other coliforms. The method will be affordable for all classes of peoples

\section{Methods}

\subsection{Research design}

An activated carbon ceramic filter was fabricated using clay and sawdust. These materials are readily available in Msambweni. The clay is found as a large residue from the Base Titanium mine. According to the company's annual reports, on average, out of the 49,000 tonnes of ore they mine per day, mineral product tonnage is only 2,000 tons per day.

On a large scale, this project would reduce volumes of left-over clay. Sawdust or coconut husks are easily found in carpenters' workshops and coconut factories in the area. Tests of physicochemical parameters, bacterial contamination, and levels of dissolved ions were carried out in the water sample collected from three water sources during the wet and dry season. The levels of physicochemical parameters were tested in situ using aquaread multiparameter equipment; microbial concentrations were done using aqua genx test kits while levels of major cations and anions were determined using Atomic Absorption Spectroscopy (AAS). These tests were done before and after water filtration using activated carbon ceramic filters to assess their effectiveness in water purification. Statistical analysis was performed by SPSS software version 21.

\subsection{The Study Area}

The Study area was the Msambweni sub-county, Kwale County, Kenya. Kwale has a total area of 8,270.3 $\mathrm{km}^{2}$ and has a total population of 866,820 people ( 2019 census). It is approximately $4^{\circ} 10^{\prime} \mathrm{S}$ and $39^{\circ} 27^{\prime} \mathrm{E}$ (www.latlong.net accessed on 23/08/2020). It experiences high humidity and temperature averaging $31^{\circ} \mathrm{C}$ making it one of the warmest regions in Kenya (Weather History of Kwale County, world data, March 2020). The long rainy season is from the end of March to the end of May, the cool and dry season from June to October, and the short rainy season from October to November. The main economic activities are fishing, subsistence farming, mining, and sugar cane 
farming. The primary water sources in the sub-county are surface water from rivers and dams, both deep and shallow underground water (Sila, 2019).
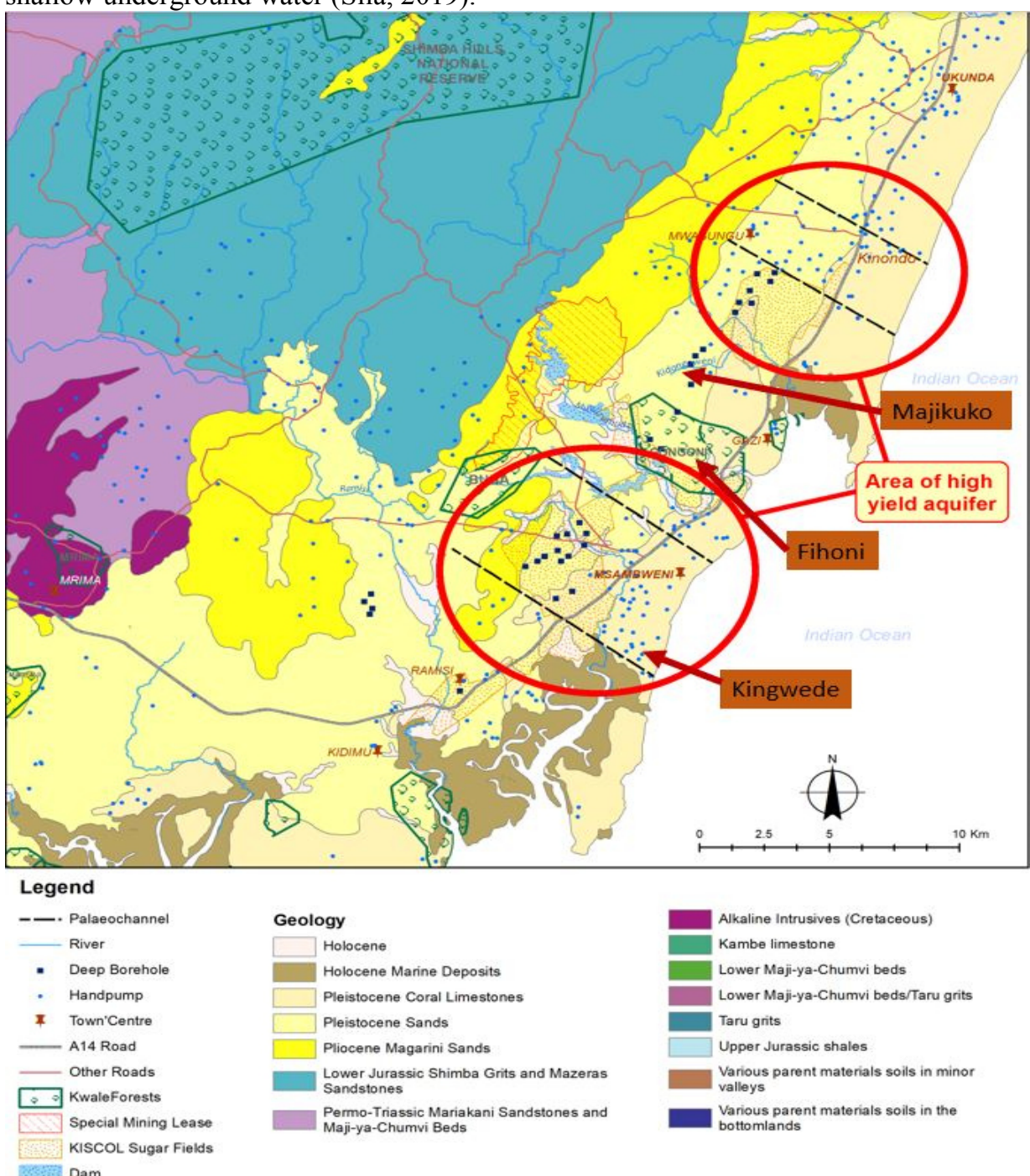

Figure 2.1: Sampling sites and water sources distribution around Msambweni. Source: University of Nairobi

\subsection{Fabrication of an Activated Carbon Ceramic Filters}

Fabrication of the filter required raw material of clay and sawdust, which were collected around Base Titanium's mine site of Kwale mineral sands company and carpentry workshop, respectively. The fabrication required a grinder, mechanical presser machine, and a methane Kiln, as detailed in appendix VI.

According to potters for peace, for better results, the clay is supposed to be ground and sieved using a 0.002 $\mathrm{mm}$ diameter sieve to make sure that it's fine and free of large debris. The fine clay should then be mixed with fine ground sawdust to form a homogenous mixture in the ratio of $6: 4$. This is to make sure more carbon is embedded in the ceramic filter (Nichols, 2016).

This results in a large amount of carbon which will increase the contact time of water with carbon because of the slow flow rate hence increasing the adsorption of contaminants. The smaller the pore size, the more effective the filter. The mixture of clay and sawdust was kneaded using warm water dissolved with $2 \mathrm{~mL}$ of $3.2 \%$ colloidal silver in $250 \mathrm{~mL}$ of filtered water (Nnaji, Afangideh \& Ezeh, 2016). This was done by adding small quantities of water until it formed a soft dough.

The kneaded dough was transferred to the presser, where it was moulded to the ceramic filter with the shape of a bucket (See appendix VI). The ceramic filter was allowed to dry with natural heat (about $29^{\circ} \mathrm{C}$ ) for three weeks. It was then taken to the methane kiln, where it was heated to temperatures of $960{ }^{\circ} \mathrm{C}$. The kiln used butane gas as a source of fuel, and a silver cone was used to detect the highest temperatures reached when it melted and started coiling since the cone usually has a melting point of $960^{\circ} \mathrm{C}$ (Zereffa \& Bekalo, 2017). 


\subsection{Water Sampling}

Sample collection of the three sites was done according to Onyuka et al., 2011. using sample containers: 2 x 500ml polypropylene container for in-situ analysis, $2 \times 1000 \mathrm{ml}$ amber glass bottle for dissolved ions, and $2 \times 500 \mathrm{ml}$ sterile plastic bottle for bacteriological analysis. These bottles had been disinfected using soap and water, cleaned using $10 \%$ nitric acid, rinsed three times with the sampled water before collection (). The procedure started with washing hands with soap, letting the water run out of the tap, collecting the sample by filling the bottle while avoiding skin contact, replacing the cap, labelling, and packaging in the transportation container.

Although the three sampling sites were different in terms of sources, the sample collection method used was grab sampling. A single sample of $500 \mathrm{ml}$ was obtained from a sample site at a specific time during the wet and dry season. Two water sets were collected at each sample site, whereby one set was filtered through the activated carbon ceramic filter. Then each of the two sets was divided into three groups insitu (physicochemical parameters), microbial contamination, and dissolved ions analysis. This resulted in six water samples per site, totaling 18 samples collected per session.

Table 2.1 GPS Coordinates of the Sample Sites

\begin{tabular}{|c|c|c|c|c|}
\hline \multirow{2}{*}{ Site } & \multicolumn{2}{|c|}{ GPS coordinates } & \multirow{2}{*}{$\begin{array}{l}\text { Well depth } \\
\text { (m) }\end{array}$} & \multirow{2}{*}{ Description } \\
\hline & Easting & Northing & & \\
\hline Kingwede (G1) & 550930 & 9503532 & \multirow[t]{2}{*}{105} & Underground (Borehole) water \\
\hline Majikuko (G2) & 553710 & 9514590 & & surface water \\
\hline Fihoni (G3) & 553726 & 9513314 & 4.84 & Open well (Handpump) \\
\hline
\end{tabular}

Samples for Insitu parameters were analyzed on-site, the bacteriological analysis was analyzed 6 hours from the time of sampling in the Base titanium's laboratory. The samples for analyses of major cations and anions were airlifted to the crop nutritional laboratory in Nairobi, Kenya, to reach not later than six hours after collection.

During transportation, they were stored in suitable cooler boxes with ice with minimal light intrusion to maintain the temperature between $1^{\circ} \mathrm{C}$ and $5^{\circ} \mathrm{C}$. Each sample bottle was labelled in the field using an appropriate waterproof label, with the sample site reference number, date, time, and sample designation. All the samples were maintained in the freezer and kept refrigerated until needed for microbiological and chemical analyses.

All the parameters were examined as outlined in stipulated procedures according to the American Water Works Association. The duplicate analysis was carried out for selected sites to check for errors involved in sampling and analysis. A procedural blank was analyzed to check for the presence of contamination or other interference with the instrument.

\subsubsection{Underground water (Borehole) sampling}

Groundwater in the well casing is not considered representative of the general groundwater at a given location. To ensure that the groundwater samples from the monitoring boreholes, which represented the water held in the subsurface strata and not water held stagnant in the borehole casing, it was necessary to evacuate the monitoring bores before sampling. A standard procedure is to pump a well until 3 bore volumes have been removed (Awual wt al., 2013). The purged volumes were calculated on-site from the measured static 'water levels (measured using an electronic well dipper T) (See appendix X).

Standard Well Volume Calculation (Kuo, 2014). 


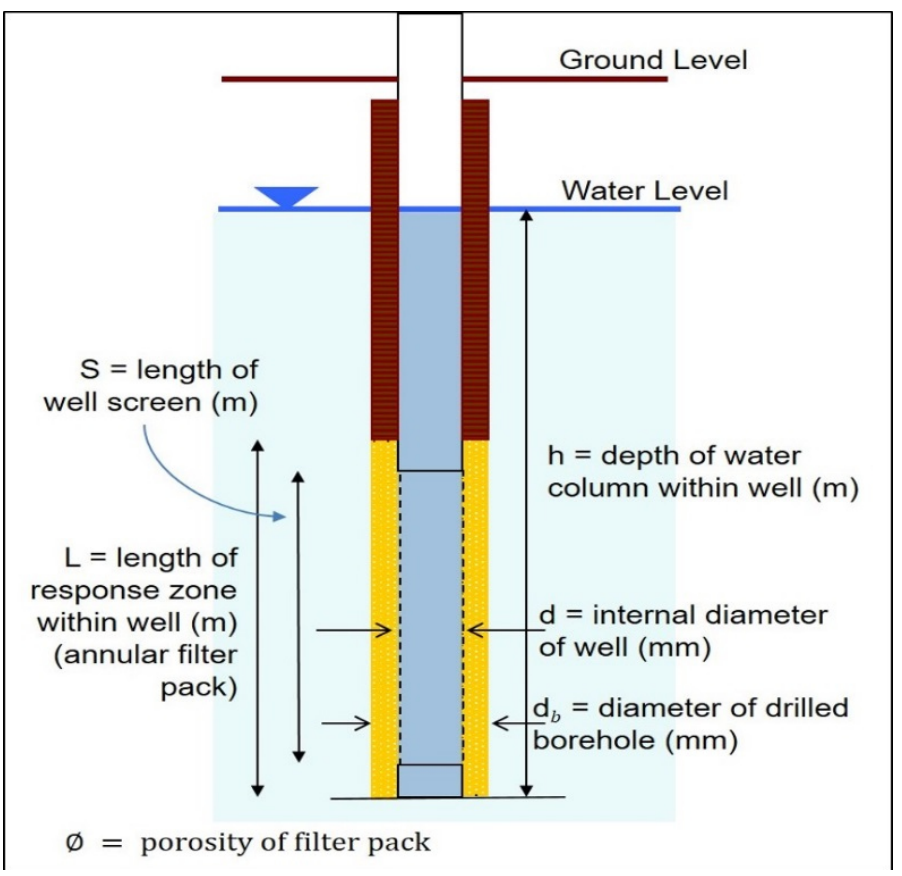

Figure 3.2: Underground water dimensions

\subsubsection{Surface water sampling}

Grab samples of surface water were collected directly into sample bottles. The sample bottle was immersed below the water surface. The water was allowed to slowly run into the bottle minimizing turbulence (Perlman, 2014). Care was taken not to disturb the sediment since analytes (such as metals) could be impacted by turbidity (Perlman, 2014).

\subsubsection{Open well sampling}

The water was pumped and left to run for 3 minutes, and samples were collected via the tap (See appendix IX).

\subsection{Instrumentation}

Various equipment was used in the study.

\subsection{Calibration of Equipment}

The calibrations for insitu water quality meters were done daily during sample testing for physicochemical analysis. The following equipment were calibrated for to measurement respectively.

\subsubsection{Hach Turbidity Meter}

It was used to measure turbidity. The zero-point calibration was performed with the instrument light source turned off (Blank or dark calibration) to remove interference from residual light in the optics or environment. The sample cell was filled with about $15 \mathrm{~mL}$ of distilled water handling the sample cell by the top. It was then capped. The cell was wiped with a soft, lint-free cloth to remove water spots and fingerprints. A thin film of silicone oil was applied and wiped with a soft cloth to obtain an even film over the entire surface. The instrument was then turned on.

The sample cell was inserted in the instrument cell compartment so that the orientation mark aligned with the raised orientation mark in front of the cell compartment. Automatic range selection was made by pressing the RANGE key. The instrument displayed AUTO RNG when it was in automatic range selection. Selected signal averaging mode by pressing the SIGNAL AVERAGE key. The display showed SIG AVG. Pressed read, and the instrument displayed 0 NTU. Recorded the turbidity after the lamp symbol turned off. The above procedure was repeated with 20 NTU and 70 NTU (Penerbit, 2014).

\subsubsection{Aqua Read Meter}

It measured electrical conductivity, turbidity, temperature, dissolved oxygen, total dissolved solids, salinity, and $\mathrm{pH}$. Calibration was done by removing the cap from a new container of Rapid Cal solution and washing the lid from the $\mathrm{pH}$ copper cathode using distilled water. The probe was then dropped inside the Rapid Cal solution bottle and gently banged on the lower side of the container several to expel air bubbles trapped by the copper cathode. After the insertion of the probe, the solution level was checked to ensure that reached it the bottleneck. Filling the solution to the bottleneck ensured that electrodes were covered. The meter was then switched on by pressing the MENU key to select the Calibration option, which gave the Rapid Cal option. After the readings were stable, the Calibrating screen displayed $100 \%$. OK was then pressed and subsequently ESC. It was calibrated at the start of 
every field day to ensure consistent results between all readings. Rapid Cal solution simultaneously calibrates EC at $2570 \mu \mathrm{S} / \mathrm{cm}, \mathrm{pH}$ at 7.00 , and turbidity at zero.

\subsubsection{Dipper-T Meter}

It was used to measure the water level. It is a manual meter that does not require calibration. At the start of each field day, it was checked that the batteries are charged.

\subsubsection{Biological contamination measurement}

Assessment of microbial contamination hazard was concerned with the presence of pathogens. For several reasons, however, pathogens are usually not studied directly. There are numerous pathogen types; they frequently occur in low concentrations, and they are often only detectable with time-consuming, costly molecular analyses that do not differentiate "dead, viable or infectious microorganisms" (Petrova et al., 2015).

Consequently, instead of detecting pathogens themselves, the study was focused on quantifying or detecting the presence of microorganisms or chemicals that indicate faecal contamination and, therefore, potential pathogen presence. This indicator approach has been common for around a century (Petrova et al., 2015), but the relationships between indicators and pathogens are not fully understood because it is difficult to compare the two directly, and such comparisons are rare (Ferguson et al., 2012).

\subsection{Analysis of dissolved ions}

The instrument was fitted with a specific lamp of the particular ion to analyze its concentration. The device was calibrated using prepared standardized solutions obtained from dilution of the standard stock solution of $1000 \mathrm{ppm}$ to desired levels. Oxy-acetylene gas was used for flaming purposes for all ions.

\subsection{Determination of Physical Parameters of Water}

Temperature, turbidity, total dissolved solids, electrical conductivity, dissolved oxygen, salinity, and $\mathrm{pH}$ were measured on-site at each sampling station.

\subsubsection{Temperature / Electrical Conductivity}

On-site analysis of EC/temperature was done using a conductivity meter which was used to measure conductivity. The conducting cells were initially standardized using recommended standards with pre-determined readings. For every analysis level, the probe cells were washed thoroughly using sublimed water; then, control was conducted for the experiment. The conductivity cells were then immersed into the analyte, then calibrated reading for EC and temperature recorded simultaneously in degrees Celsius and micro Siemen units.

\subsubsection{Turbidity}

A turbid meter was used in situ (Nephelometric). The sample cell was filled with sample water to the line (about $15 \mathrm{~mL}$ ) to handle the sample cell by the top. It was then capped. The cell was wiped with a soft, lint-free cloth to remove water spots and fingerprints. A thin film of silicone oil was applied and wiped with a soft cloth to obtain an even film over the entire surface. The instrument was then turned on. The sample was inserted in a sample cell in the instrument cell compartment so that the orientation mark aligned with the raised orientation mark in front of the cell compartment. Pressed read and the instrument displayed the turbidity readings.

\subsubsection{Total Dissolved Solids}

TDS for 12 samples of water was determined using the gravimetric method as indicated by (Teshome 2020). A $100 \mathrm{ml}$ filtrate was poured in a dried, pre-weighed porcelain container, evaporated to dryness inside an oven maintained at $105^{\circ} \mathrm{C}$ for 1 hour 30 minutes for standardized dryness. Finally, the resultant residue was transferred to desiccators to cool to standard dryness to attain constant weight. The constant weight attained was calculated as the TDS.

\subsubsection{Dissolved Oxygen}

DO was analyzed using a DO-meter probe in the aquaread meter. A pre-rinsed probe was immersed approximately 1.25 inches into the 12 samples, and stabilized readings were taken during analysis. The stabilized readings were read after waiting for the meter to stabilize on the digital screen (Teshome, 2020).

\subsubsection{Salinity}

Water salinity is measured by passing an electric current between the two electrodes of a salinity meter in sample water (Corwin \& Yemoto, 2020). The electrical conductivity of the water sample is determined by the amount and composition of dissolved salts. Salts increase the ability of a solution to conduct an electrical current, so a high EC value indicates a high salinity level (Peralta \& Costa, 2013).

\subsubsection{Potential of Hydrogen (pH)}

A potentiometric $\mathrm{pH}$ measure was carried out on-site using a calibrated $\mathrm{pH}$ meter. For every analysis level, the probes were extremely cleaned by the use of water immediately every reading was finished and dipped 1.25 inches inside the sample, and then standardized measures were recorded.

\subsection{Bacteriological Analysis}

The 12 samples were analyzed for their bacteriological quality. The bacteriological analysis involved presumptive, 
confirmatory, and completed tests. Presumptive test analysis was done to obtain total coliforms, while confirmatory test analysis was conducted using brilliant green broth to obtain faecal coliforms. Samples were collected in sterilized bottles. Care was taken not to touch the inside of the lid's bottle rim and not to allow the water to splash off hands or other bottle surfaces. The containers were filled, leaving a half-inch of air space between the top of the bottle and the collected water (Ho et al., 2019).

\subsubsection{Presumptive Analysis for total coliform}

The absence or presence of total coliforms was determined by multiple tube fermentation processes using Mac Conkeybroths. The double and single strength broth preparations were injected with loopful samples and stored in an incubator at $37^{\circ} \mathrm{C}$ for 24 hours, after which the findings were interpreted for the presence or absence of total coliforms based on lactose fermentation and gas production (Rojas et al., 2020).

The analysis from the results was read against standards. Positive indicators of Mac Conkey broth changing from purple to yellow due to lactose formation indicated the presence of total coliform. This was also shown by the production of gas inside the Durham tube or turbidity. Negative results indicated the absence of the gas and purple colour persistence (Haylamicheal and Moges, 2012).

\subsubsection{Confirmatory Analysis}

\section{Faecal Coliform Bacteria Test Analysis}

The analysis was done only for the samples that tested positive for total coliforms. The analysis was done using brilliant green broth preparations, as shown in figure 3.6. A loop is full of samples that indicated positive total coliforms were transferred onto respective brilliant green broth and enumerated after overnight incubation at $44.5^{\circ} \mathrm{C}$. The results were read and interpreted based on gas production inside the Durham tubes. The test results were read against known positive standards such that faecal coliform indicated gas production inside the Durham tubes or turbidity of the broth.

\section{Use of Aqua genx Test Kits}

The most probable number (MPN) concentrations of E. coli were determined using compartmental bag test (CBT) kits in accordance with the procedures recommended by the manufacturer (Hawes et al., 2015). MPN testing involves multiple presence/absence tests on different volumes of the same sample. Statistical tables are used to estimate E. coli concentrations based on the combination of results. Fresh CBT II kits, purchased in the month prior to sampling, were used. The growth medium (which contains chromogenic substrate: 5-Bromo-4-chloro-3indolyl-beta $\neg \mathrm{D}$ - glucuronic acid) was stored in a refrigerator but never frozen.

Hand sanitiser was used prior to collecting each sample, and the inside and openings of the bags were not touched. The sample water was pumped/poured into a plastic jug and then immediately poured into the Thio bags. This was done because the jar allowed better pouring to collect exactly $100 \mathrm{~mL}$ and keep the outside of the bag clean and dry. The jug was regularly sanitized with ethanol and triple rinsed with the sample water immediately before collecting each sample. Samples were stored out of direct sunlight immediately after collection. They were incubated at $40^{\circ} \mathrm{C}$ for at least twenty-four and no more than thirty hours. The transport container and incubator were sanitized with ethanol between sample batches.

\subsection{Determination of dissolved ions in Water}

Atomic absorption spectrometry was used. A Perkin-Elmer Model analyst 200 Atomic Absorption Spectrophotometer equipped with a single element hollow cathode lamp and $10 \mathrm{~cm}$ air-acetylene burner was used to determine the metals ions. Standard solutions of known metal concentrations were prepared in water with a matrix similar to the sample. For samples containing high and variable concentrations of matrix materials, the major metal species in the sample and the dilute standard was made in the same way.

Standard additions methods were used if the sample matrix was complex and components could not be matched accurately with standards. All data were reported as ppm metal (i.e. milligrams metal per litre). Samples were filtered before use and the sample aspirated into the flame. Since the spectrometer uses a different lamp for each metal to be analyzed, a complete analysis of one metal was done (calibration curve and duplicate sample measurements) before commencing the analysis of another metal. Metals to be determined by AAS included manganese, iron, sodium, potassium, and calcium.

\subsection{Data Analysis}

The level of physicochemical parameters, bacterial content, major cations, and anions was analyzed before and after passing the water samples through the filter. These levels were then compared to those allowed by the WHO to gauge the efficiency of the sieve in the purification of water. Statistical analysis was performed by SPSS software version 21. Variations among the sampling locations were compared through one-way ANOVA. Tukey's post hoc test for several comparisons was conducted on statistically significant data. Variations amongst the sampling unfiltered and filtered water samples were analyzed using paired t-test. Correlation between selected physicochemical parameters $(\mathrm{p}<0.05)$ in the 18 water samples was conducted using Pearson's correlation $(\mathrm{r})$. The findings were presented in tables and figures. 


\section{Results and discussion}

The study was aimed at investigating the effectiveness of an activated carbon ceramic filter in water purification. This involved testing surface and underground water for physicochemical, microbial properties, and dissolved ions before and after filtration using the activated carbon ceramic filter. The water sources were from Fihoni (open well /Hand pump), Kingwede (borehole/underground), and Majikuko (Surface/ River) areas of Msambweni SubCounty, Kwale County.

\section{1: Physical Properties of Water in Msambweni}

The standard error of the mean, mean \pm SE, levels of the different physical properties of water samples obtained from Fihoni (open well /Hand pump), Kingwede (borehole/underground), and Majikuko (Surface/ River) sampling sites are presented in table 4.1. They included temperature, turbidity, Dissolved Oxygen (DO), electrical conductivity (EC), $\mathrm{pH}$, total dissolved solids (TDS), and salinity.

Table 3.1: Mean \pm SE, standard deviation from the mean of the Levels of Physical water sample characteristics from Majikuko, Kingwede, and Fihoni Areas

\begin{tabular}{lllllllll}
\hline Site & Mean & & & & & \\
\pm SE & $\mathrm{XX}$ & Temp $\left({ }^{0} \mathrm{C}\right)$ & Trb (NTU) & TDS (mg/L) & DO & Salinity & pH & EC \\
\hline Majikuko & $\mathrm{BF}$ & $22.92 \pm 0.87$ & $5.25 \pm 0.01$ & $51.12 \pm 31.85$ & $5.94 \pm 0.48$ & $5.17 \pm 0.56$ & $7.37 \pm 0.15$ & $0.87 \pm 0.03$ \\
& $\mathrm{AF}$ & $20.90 \pm 0.86$ & $1.17 \pm 0.01$ & $50.13 \pm 30.84$ & $4.75 \pm 0.38$ & $4.18 \pm 0.54$ & $5.87 \pm 0.01$ & $0.33 \pm 0.06$ \\
p-value & $<0.001$ & & & & & & & \\
Kingwede & $\mathrm{BF}$ & $22.72 \pm 1.15$ & $4.99 \pm 0.01$ & $68.62 \pm 66.93$ & $7.48 \pm 0.33$ & $3.85 \pm 0.78$ & $7.27 \pm 0.01$ & $0.18 \pm 0.01$ \\
& $\mathrm{AF}$ & $20.47 \pm 1.12$ & $1.13 \pm 0.01$ & $67.77 \pm 65.54$ & $6.80 \pm 0.32$ & $2.89 \pm 0.75$ & $6.85 \pm 0.01$ & $0.08 \pm 0.00$ \\
p-value & $<0.001$ & & & & & & & \\
Fihoni & $\mathrm{BF}$ & $23.24 \pm 1.22$ & $30.00 \pm 1.00$ & $62.81 \pm 14.53$ & $4.21 \pm 0.96$ & $4.42 \pm 0.67$ & $7.46 \pm 0.02$ & $0.28 \pm 0.01$ \\
& $\mathrm{AF}$ & $22.23 \pm 1.10$ & $0.88 \pm 0.01$ & $62.73 \pm 13.53$ & $3.83 \pm 0.89$ & $4.12 \pm 0.57$ & $6.25 \pm 0.01$ & $0.02 \pm 0.00$ \\
\multicolumn{2}{l}{ WHO Standards } & $<25.0$ & $<5.0$ & Max. 500 & $>5.0$ & Max.250.0 & $6.5-8.5$ & $<1.50$
\end{tabular}
p-value $<0.001$

Water samples tested from the three sampling points exhibited a significant difference in the physical properties before and after filtration $(\mathrm{p}<0.001)$, as indicated by the T. test. AF-After Filtration; BF-Before Filtration; Temp.-Temperature, Trb-Turbidity, NTU-Nephelometric Turbidity Unit, TDS-Total Dissolved Solid, DODissolved Oxygen, and EC-Electrical Conductivity.

The data in Table 4.1 indicates the observable properties values of the water samples before and after filtration were all within the acceptable range according to WHO regulations, of below $25^{\circ} \mathrm{C}$ for temperature, turbidity below 5.0 NTU, TDS below 1,500mg/L, DO above5.0, salinity below 250, PH between 6.5-8.5 and EC below 1.50. However, the turbidity and DO were beyond the recommended limits at $(30.00 \pm 1.00 \mathrm{NTU})$ and DO $(4.21 \pm 0.96 \mathrm{mg} / \mathrm{L})$ from water samples collected from Fihoni.

The mean $\pm \mathrm{SE}$ ranged from 22.72 $\pm 1.15-23.24 \pm 1.220 \mathrm{C}$ (Temperature); 4.99 $\pm 0.01-30.00 \pm 1.00$ NTU (Turbidity), $51.12 \pm 31.85-68.62 \pm 66.93 \mathrm{mg} / \mathrm{L}$ (TDS), $4.21 \pm 0.96-7.48 \pm 0.33 \mathrm{mg} / \mathrm{L}$ (DO2), $3.85 \pm 0.78-5.17 \pm 0.56$ $\mathrm{mg} / \mathrm{L}$ (salinity), 7.37 $\pm 0.15-7.46 \pm 0.02(\mathrm{pH})$ and $0.18 \pm 0.01-0.87 \pm 0.03 \mathrm{mg} / \mathrm{L}$ (EC). These levels decreased significantly after filtration of the water samples using the activated carbon, with the water samples from Fihoni registering the lowest levels in $\mathrm{EC}$ of $0.02 \pm 0.00 \mu \mathrm{S} / \mathrm{cm}$. as seen in figures 3.1 to 3.7 below

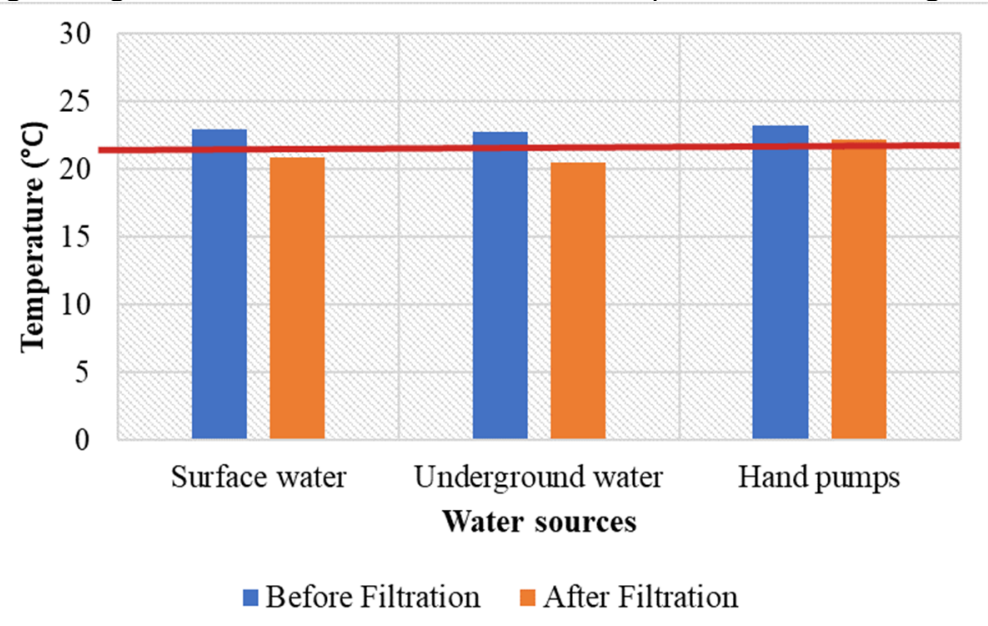

Figure 3. 1: Average Temperature levels for water samples before and after filtration

All the temperature values from all samples were below the WHO guideline of $25^{\circ} \mathrm{C}$ for both filtered and unfiltered samples. The temperatures of filtered water were lowest at each sampling point. The temperature for 
each sample dropped after filtration through the activated carbon ceramic filter. Water placed in earthen pots is evaporated from minuscule pores it has as it is made of mud particles. This evaporation of water produces a cooling effect. Some of the heat energy that is generated is used in the process of evaporation. Hence, water stored in earthen pots tends to become cooler (Kaurwar et al., 2017).

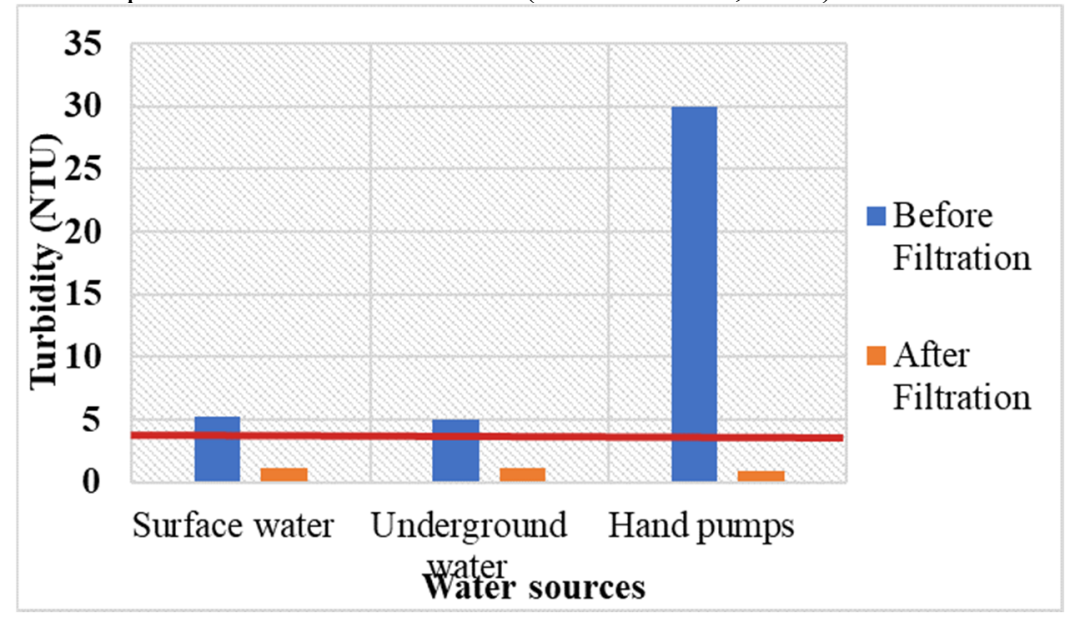

Figure 3. 2: Average Turbidity levels for water samples before and after filtration

The study revealed that there were high turbidity levels above the 5 NTU recommended by WHO for water samples from the hand pump and surface water. This can be attributed to clay, silt, finely dissolved organic and inorganic materials. The turbidity levels dropped when the samples were filtered to within recommended values.

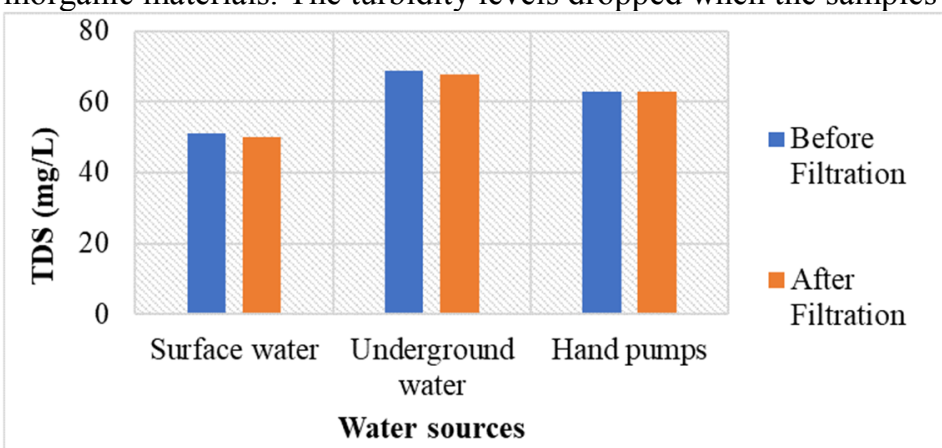

Figure 3. 3: Average TDS for water samples before and after filtration

The WHO standard for total dissolved solids (TDS) is $<500 \mathrm{mg} / \mathrm{L}$. All samples before and after filtration were within limits. The results show that the activated carbon ceramic filter has no significant effect on the TDS.

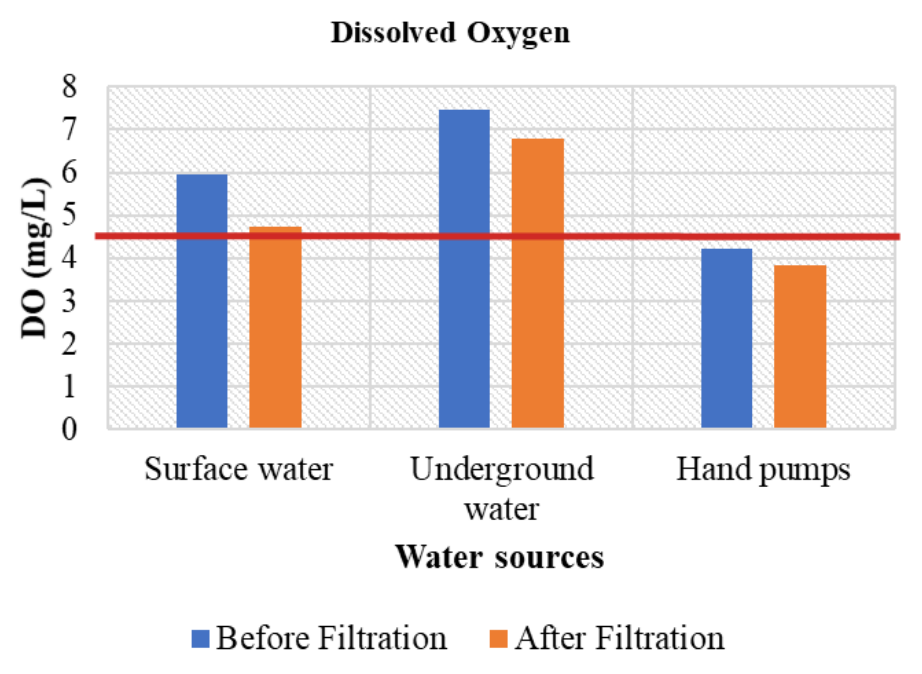

\section{Figure 3. 4: Average DO for water samples before and after filtration}

The WHO recommended values of dissolved oxygen (DO) are to be $>5.0 \mathrm{mg} / \mathrm{L}$. Unfiltered water from hand pumps had lesser DO. This is a natural phenomenon in underground water. The levels also dropped slightly after filtration 


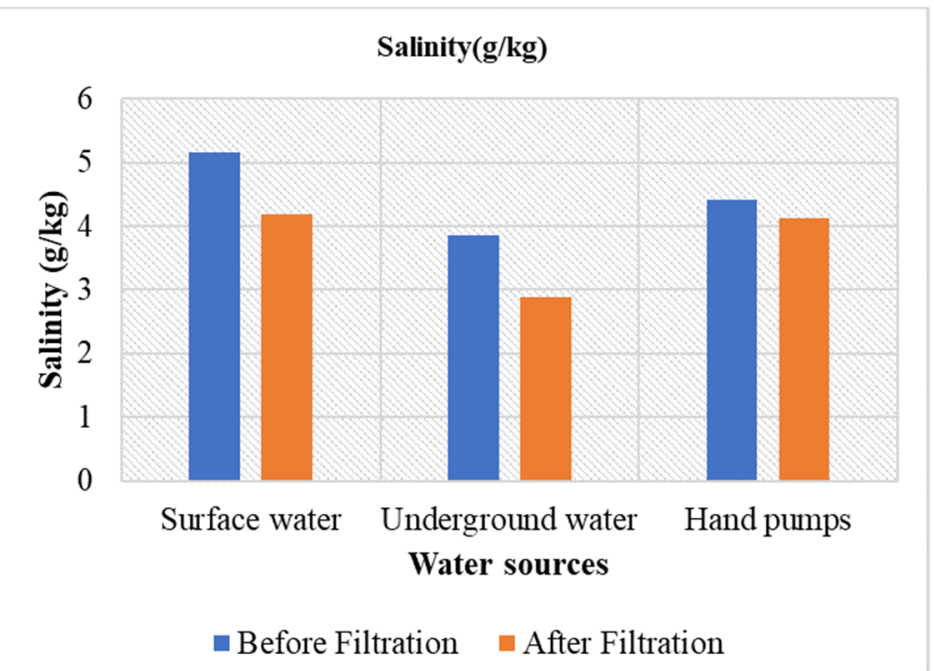

Figure 3. 5: Average salinity levels for water samples before and after filtration

The WHO recommended salinity levels in drinking water is supposed to be $<250 . \mathrm{g} / \mathrm{kg}$. All the samples were within recommended levels, with filtered samples even being much lesser.

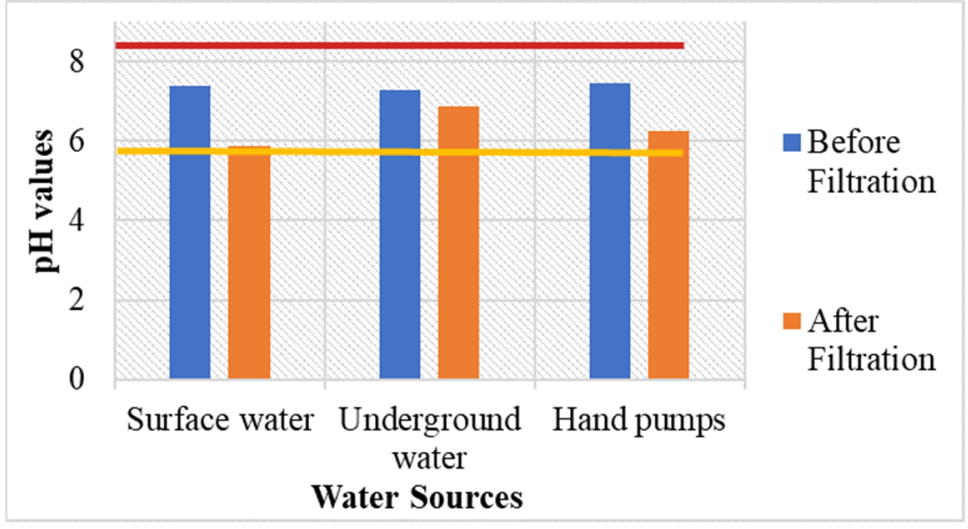

Figure 3. 6: Average PH values for water samples before and after filtration

The water samples from the three sites before filtration were all within the WHO guidelines. The filtered samples slightly dropped outside the PH range of 6.5-8.5 showing slight acidity.

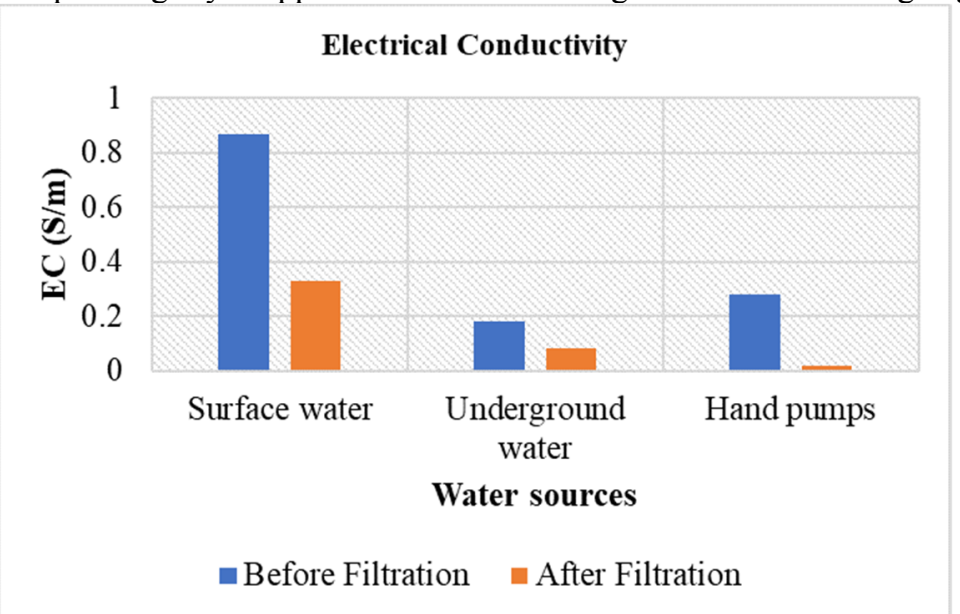

Figure 3. 7: Average EC for water samples before and after filtration

The samples had electrical conductivity (EC) less than 1.50 as recommended by WHO. The EC even dropped further after filtration.

The differences in the samples collected at Fihoni can be attributed to the removal of the ions by the activated carbon ceramic filter hence their low concentration in the water samples. Differences between the sites showed that Fihoni and Kingwede had the highest levels of turbidity and TDS of $(30.00 \pm 1.00 \mathrm{NTU})$ and TDS $(68.62 \pm 66.93$ $\mathrm{mg} / \mathrm{L}$ ), respectively. The high turbidity in water samples obtained from the Fihoni area could be due to the 
availability of suspended materials such as planktons, bacteria, and dissolved organic.

The presence of high inorganic substances can also be the reason as to why there was a variation. The results are supported by Rojas et al. (2020), who noted similar findings. The t-test showed that the average figures of the physical parameters significantly differed before and after the filtration of the water samples $(\mathrm{p}<0.001)$. The results can be attributed to the increased efficiency of the ceramic filters due to the small pores in the added clay. The study results corroborate Petrova et al. (2015) on the efficacy of ceramic filters.

Comparison between the three sites (Majikuko, Kingwede, and Fihoni) showed that water samples from Kingwede had a significantly higher level of TDS before (68.62 \pm 66.93$)$ and after filtration (67.77 \pm 65.54$)$. The findings can be associated with massive pollution within the area because of titanium mining activities. The results concur with (Beaulieu, Pick \& Gregory-Eaves, 2013), who notes that one of the significant predictors of water standards is the number of human practices in a given area.

The high levels of TDS can be associated with elevated water temperature and low $\mathrm{pH}$. Excessive temperature is caused by several aspects ranging from the transfer of heat from the atmosphere, active solar radiation, turbidity, and river confluence (Dugdale, Hannah \& Malcolm, 2017). Elevated temperature limits tolerance levels of biological organisms and accelerates the solubility of toxic substances. Therefore, it implies that high water temperatures recorded in this study can be correlated with heavy metal loads such as lead (Bhardwaj, Gupta \& Garg, 2017).

In this study, water $\mathrm{pH}$ was within the acceptable limits (between 6.5 and 8.5) before and after filtration. The $\mathrm{pH}$ decreased from $7.46 \pm 0.02$ to $6.85 \pm 0.01$ before and after samples of water from Fihoni was filtered. The alkaline $\mathrm{pH}$ can be due to the discharge or seepage of industrial pollutants containing silicates and phosphates into the underground water sources, as suggested by (O'Connor et al., 2018). High water $\mathrm{pH}$ above the maximum permissible levels is unfit because it potentially affects people and animals indirectly. High water $\mathrm{pH}$ causes inflammation and irritation of human mucous membranes, exposing them to more opportunistic illnesses (Agustin, 2016).

Table 3. 2: T-test of physicochemical Properties of Samples of the Water

\begin{tabular}{llllllll}
\hline Test Variable & Filtration & $\mathrm{N}$ & Mean & Std. Deviation & Std. Error Mean & T & Sig. (2-tailed) \\
\hline Temp & Unfiltered & 6 & 23.43 & 0.224 & 0.075 & -1.602 & 0.129 \\
& Filtered & 6 & 21.84 & 1.887 & 0.962 & -1.602 & 0.148 \\
PH & Unfiltered & 6 & 6.33 & 0.144 & 0.048 & -9.404 & 0 \\
& Filtered & 6 & 7.12 & 0.21 & 0.07 & -9.404 & 0 \\
DO & Unfiltered & 6 & 9.06 & 0.36 & 0.12 & 4.519 & 0 \\
& Filtered & 6 & 6.1 & 1.933 & 0.644 & 4.519 & 0.002 \\
EC & Unfiltered & 6 & 250.89 & 251.19 & 83.73 & -1.38 & 0.186 \\
& Filtered & 6 & 463.56 & 388.013 & 129.338 & -1.38 & 0.19 \\
TDS & Unfiltered & 6 & 168.22 & 167.489 & 55.83 & -1.315 & 0.207 \\
& Filtered & 6 & 301 & 252.364 & 84.121 & -1.315 & 0.21 \\
Salinity & Unfiltered & 6 & 0.09 & 0.101 & 0.034 & -1.342 & 0.198 \\
& Filtered & 6 & 0.19 & 0.196 & 0.065 & -1.342 & 0.204 \\
Turbidity & Unfiltered & 6 & 1.09 & 0.912 & 0.304 & -3.919 & 0.001 \\
& Filtered & 6 & 14.82 & 10.471 & 3.49 & -3.919 & 0.004 \\
\hline
\end{tabular}

The results from Table 4.3, where $\mathrm{n}$ is the number of tests done, indicated that there was an insignificant mean variation between the filtered and unfiltered underground and surface water temperature, i.e. $0.148>0.05$. The mean difference showed between the $\mathrm{pH}$ of the filtered and unfiltered underground and surface water was found to be statistically significant $(0.000<0.05)$. This was supported by a $\mathrm{T}$ - statistic, which was more significant than the critical value $(-1.602>-1.96)$.

The mean difference indicated between the dissolved oxygen of the filtered and unfiltered underground and surface water was likewise found to be statistically significant $(0.000<0.05)$. The contrast of the water qualities can be attributed to the fact that ceramic filters remove ions and cations responsible for water $\mathrm{pH}$. The findings are similar to Roohul et al. (2012).

However, the mean difference between the electrical conductivity of the filtered and unfiltered underground and surface water was found not to be significant. This was indicated by a p-value exceeding 0.05 . The results also showed an insignificant mean difference between the filtered and unfiltered underground and surface water salinity. The results are attributed to the possibility that the water in the area has few dissolved salts, which are responsible for electrical conductivity and salinity. Ponce (2014) made similar observations. This was indicated by a p-value of 0.204 .

The results, however, reported a significant mean difference in the turbidity of the filtered and unfiltered underground and surface water $(0.004<0.05)$. The mean difference in the findings could be a result of anthropogenic activities that affect the water turbidity. Dai et al. (2018) made similar observations due to social activities such as mining and agriculture. 


\subsection{Microbial Quality of Water in Msambweni}

The Mean \pm SE levels of the total coliforms $(\mathrm{CFU} / 100 \mathrm{ml})$ and faecal coliforms (MPN) in water sampled from Fihoni (open well /Hand pump), Kingwede (borehole/underground), and Majikuko (Surface/ River) areas of Msambweni Sub-County, Kwale County were presented in table 4.4. The initial concentrations of E. coli and total coli from the three water sites used for the microbial removal test were found to be $100 \%$ effective. The result of this study agrees with the finding of Petrova et al. (2015), who reported that ceramic filters could remove microorganisms efficiently.

During ceramic filters firing, the burnouts leave smaller pores of about 1-micron size, which filter out the most harmful microbes. Microorganisms with large sizes are blocked within the pore and refrained from flowing through the ceramic element (Bulta \& Micheal, 2019). Also, Aliyu, Usman and Audu (2019) reported that ceramic water filters have good efficiency in removing microbial from bacterially contaminated water sources. When microorganisms pass through the pores of ceramic filters, there might be strong suffocation on their path due to the path's tortuosity. At the same time, they compete for feeding, which reduces the number of microbial after filtration (Alemayehu, 2018).

Table 3. 3 Mean \pm SE Total Coliforms (CFU/100ml) and Faecal Coliforms (MPN)

\begin{tabular}{|c|c|c|c|}
\hline Sampling site & & E. Coli $(\mathrm{CFU} / 100 \mathrm{ml})$ & Total coliform $(\mathrm{CFU} / 100 \mathrm{ml})$ \\
\hline \multirow[t]{3}{*}{ Majikuko } & $\mathrm{BF}$ & $5.00 \pm 0.00$ & $25.00 \pm 0.00$ \\
\hline & $\mathrm{AF}$ & ND & ND \\
\hline & $\mathrm{p}$-value & $<0.001$ & $<0.001$ \\
\hline \multirow[t]{3}{*}{ Fihoni } & $\mathrm{BF}$ & $3.00 \pm 0.00$ & $18.00 \pm 0.00$ \\
\hline & $\mathrm{AF}$ & ND & ND \\
\hline & p-value & $<0.001$ & $<0.001$ \\
\hline \multirow[t]{3}{*}{ Kingwede } & $\mathrm{BF}$ & $1.00 \pm 0.00$ & $12.00 \pm 0.00$ \\
\hline & $\mathrm{AF}$ & ND & ND \\
\hline & p-value & $<0.001$ & $<0.001$ \\
\hline WHO standards & & NIL & NIL \\
\hline
\end{tabular}

A T-test indicated that there was a significant difference in the biological properties of water before and after filtration $(\mathrm{p}<0.001)$. AF-After Filtration; BF-Before Filtration; CFU-Colony Forming Unit; MPN-Most Probable Number; ND-Not Detected.

Table 3.4 shows how the total coliforms and faecal $E$. coli were distributed in the water obtained from the three sampling locations, namely Fihoni (open well /Hand pump), Kingwede (borehole/underground), and Majikuko (Surface/ River). Water samples from the three locations tested positive for total coliforms and Faecal E. coli. The results are similar to those conducted by Swanson et al. (2018). The levels of Faecal E. coli and total coliform before filtration ranged between $1.00 \pm 0.00$ to $5.00 \pm 0.00$ and $12.00 \pm 00$ to $25.00 \pm 0.00$, respectively, which were well above the WHO standards (WHO, 2017). These levels, however, decreased significantly to WHO permissible levels after filtration.

The total coliform and faecal E. coli levels were significantly higher in Majikuko (surface water), followed by the Fihoni (hand pump) then Kingwede (underground) water, which might be a result of large volumes of surface run-off. The surface water site was used as cattle drinking and bathing points for humans at different sites along the stream. The shallow underground water (hand pumps) was also microbially contaminated because of the proximity to latrines. The animal and human wastes contribute to increased levels of both total coliform and Faecal E. coli (Purohit et al., 2017). This can also be attributed to human activities such as washing clothes and defecation areas for humans (WHO, 2017). The low levels in underground water were due to minimal contamination because the surface water gets filtered out as it recharges the aquifer below the ground. 


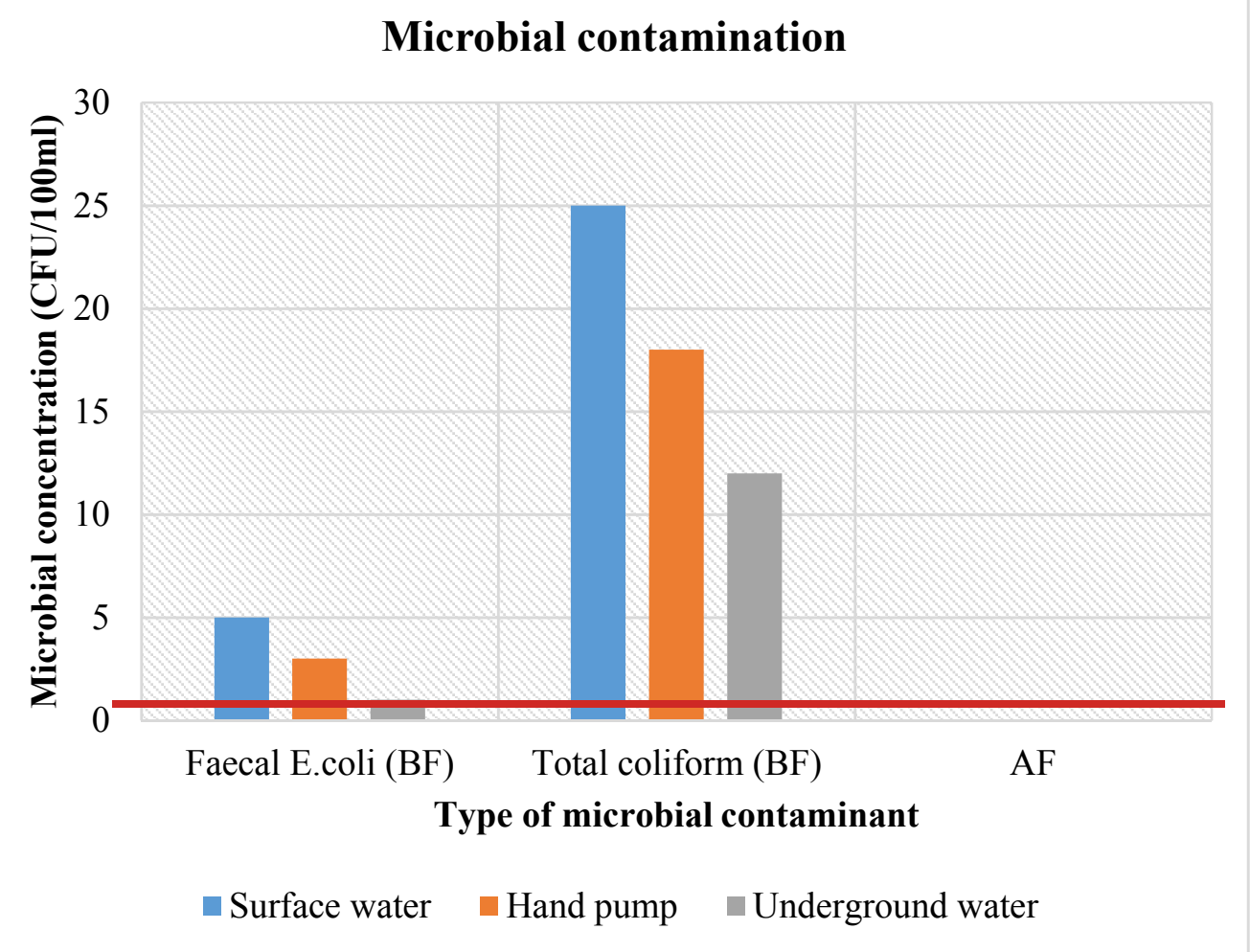

Figure 3. 8: Average microbial contamination in the water sources

3.3.1 Descriptive Results for Total Coliforms and Faecal $\boldsymbol{E}$. coli

The mean of faecal E. Coli CFU/100 ml) detected in the underground and surface water was higher in the unfiltered water as compared to the mean faecal $E$. coli $(\mathrm{CFU} / 100 \mathrm{ml})$ detected in filtered underground and surface water that is $(2.83 \mathrm{v} 0)$ as shown in the table below.

Table 4.4: Descriptive results for Total Coliforms (CFU/100ml) and faecal Coliforms (CFU/100ml)

\begin{tabular}{|llllllllll|}
\hline \multirow{2}{*}{ Test Variable } & & $\mathrm{N}$ & Mean & Std. Dev & Std. Error & $\begin{array}{l}95 \% \text { C.I } \\
\text { L.B }\end{array}$ & $\begin{array}{l}\text { Min } \\
\text { U.B }\end{array}$ & & Max \\
\hline Feacal E. coli $(\mathrm{cfu} / 100 \mathrm{ml})$ & Unfiltered & 6 & 2.83 & 1.472 & 0.601 & 1.29 & 4.38 & 1 & 5 \\
& Filtered & 6 & 0 & 0 & 0 & 0 & 0 & 0 & 0 \\
& Total & 12 & 1.42 & 1.782 & 0.514 & 0.28 & 2.55 & 0 & 5 \\
Total Coliforms $(\mathrm{cfu} / 100 \mathrm{ml})$ & Unfiltered & 6 & 14.67 & 5.888 & 2.404 & 8.49 & 20.9 & 9 & 25 \\
& Filtered & 6 & 0 & 0 & 0 & 0 & 0 & 0 & 0 \\
& Total & 12 & 7.33 & 8.627 & 2.49 & 1.85 & 12.8 & 0 & 25 \\
\hline
\end{tabular}

The mean of total coliforms (CFU/100 ml) detected in the underground and surface water was higher in the unfiltered water as compared to the mean faecal $E$. coli $(\mathrm{CFU} / 100 \mathrm{ml})$ detected in filtered underground and surface water that is $(14.67 \mathrm{v} 0)$. The variation of the total coliform count is due to the effectiveness of the ceramic filter in the removal of bacteria from the water. The findings are supported by Bulta \& Micheal, 2019).

3.3.2 Test for Equality of Means for Total Coliforms and faecal $E$. coli

The results showed in Table 4.5 underscored various mean differences and their significance. The mean difference between Faecal E. coli $(\mathrm{CFU} / 100 \mathrm{ml})$ found in unfiltered and filtered underground as well as surface water was statistically significant $(0.001<0.05)$.

Table 3 5:T-test for Total Coliforms (CFU/100ml) and faecal Coliforms (MPN)

\begin{tabular}{|llllllll|}
\hline Test Variable & Filtration & $\mathrm{N}$ & Mean & Std. Deviation & Std. Error Mean & $\mathrm{t}$ & $\begin{array}{l}\text { Sig. } \\
(2 \text {-tailed) }\end{array}$ \\
\hline Feacal E. Coli (cfu/100 ml) & Unfiltered & 6 & 2.83 & 1.472 & 0.601 & 4.715 & 0.001 \\
& Filtered & 6 & 0 & 0 & 0 & 4.715 & 0.005 \\
Total Coliforms (cfu/100 ml) & Unfiltered & 6 & 14.7 & 5.888 & 2.404 & 6.102 & 0 \\
& Filtered & 6 & 0 & 0 & 0 & 6.102 & 0.002 \\
\hline
\end{tabular}

The mean difference between total coliforms $(\mathrm{CFU} / 100 \mathrm{ml})$ in the filtered and unfiltered underground as well as surface water was also found to be statistically significant. According to Farrow et al. (2018), ceramic water filters can reduce a significant number of bacteria from the water. The findings are consistent with this since a high variation was noted between unfiltered and filtered water samples. 


\subsection{Ionic Properties of Water in Msambweni}

The ionic properties of water sampled from Fihoni (open well /Hand pump), Kingwede (borehole/underground), and Majikuko (Surface/ River) areas of Msambweni Sub-County of Kwale County for selected ions $\left(\mathrm{Na}^{+}, \mathrm{Ca}^{2+}\right.$, $\mathrm{Mg}^{2+}, \mathrm{HCO}_{3}^{-}, \mathrm{K}^{+}, \mathrm{Cl}^{-}$and $\mathrm{SO}_{4}{ }^{2-}$ ) are shown in Table 4.7

Table 4. 6: Ionic properties of water samples from Majikuko, Kingwede, and Fihoni Areas

\begin{tabular}{|lllllllll|}
\hline Sampling site & & $\mathrm{Na}^{+}$ & $\mathrm{K}^{+}$ & $\mathrm{Ca}^{2+}$ & $\mathrm{Mg}^{2+}$ & $\mathrm{HCO}_{3}^{-}$ & $\mathrm{Cl}^{-}$ & $\mathrm{SO}_{4}^{2-}$ \\
\hline Majikuko & BF & $64.20 \pm 0.20$ & $55.33 \pm 0.60$ & $63.70 \pm 0.26$ & $11.70 \pm 0.10$ & $225.67 \pm 0.58$ & $98.67 \pm 0.06$ & $28.60 \pm 0.10$ \\
& AF & $30.50 \pm 0.10$ & $18.60 \pm 0.10$ & $6.30 \pm 0.10$ & $6.15 \pm 0.01$ & $<\mathrm{LOD}$ & $64.00 \pm 1.00$ & $15.80 \pm 0.10$ \\
P-value & & & & & & $<0.001$ & & \\
Kingwede & BF & $11.33 \pm 1.53$ & $1.17 \pm 0.06$ & $23.23 \pm 0.06$ & $1.04 \pm 0.01$ & $55.17 \pm 1.04$ & $10.00 \pm 1.00$ & $8.06 \pm 0.01$ \\
& AF & $8.53 \pm 0.06$ & $6.38 \pm 0.01$ & $4.07 \pm 0.01$ & $2.05 \pm 0.01$ & $<\mathrm{LOD}$ & $7.25 \pm 0.01$ & $5.71 \pm 0.01$ \\
P-value & & 0.031 & $<0.001$ & $<0.001$ & $<0.001$ & $<0.001$ & $<0.001$ & $<0.001$ \\
Fihoni & BF & $15.43 \pm 0.15$ & $7.37 \pm 0.01$ & $37.20 \pm 0.10$ & $4.47 \pm 0.01$ & $132.67 \pm 0.58$ & $12.87 \pm 0.06$ & $2.76 \pm 0.01$ \\
& AF & $2.86 \pm 0.02$ & $3.46 \pm 0.01$ & $1.99 \pm 0.01$ & $0.35 \pm 0.01$ & $<$ LOD & $3.05 \pm 0.02$ & $3.24 \pm 0.01$ \\
P-value & & & & & $<0.001$ & & & \\
WHO & & Max. 200 & $<100$ & $<75$ & $<30$ & $<200$ & $<250$ & 250 \\
standards & & & & & & & & \\
\hline
\end{tabular}

The amounts $(\mathrm{mg} / \mathrm{L})$ of the mineral ions before filtration $(\mathrm{BF})$ ranged from $1.04 \pm 0.01$ in Kingwede for $\mathrm{Mg}^{2+}$ to $225.67+0.58$ for $\mathrm{HCO}_{3}{ }^{-}$in the water samples obtained from Majikuko. After filtration, these levels significantly decreased to $0.35 \pm 0.01$ for $\mathrm{Mg} 2+$ and $30.50+0.10$ for HCO3- in Fihoni and Majikuko water samples. The levels were as per WHO's maximum recommended levels. The t-test also indicated negligible variations in the amounts of all the mineral ions between the three sampling locations.

The concentration $(\mathrm{mg} / \mathrm{L})$ of $\mathrm{Ca}^{2+}$ from the study areas ranged from $23.23 \pm 0.06$ (Kingwede) to $63.70 \pm 0.26$ (Majikuko) before filtration. The acceptable levels of $\mathrm{Ca}^{2+}$ for potable water are stipulated as $75 \mathrm{mg} / \mathrm{L}$ (WHO, 2017). According to the recommendation, the underground and surface water from these areas are suitable for human consumption. The most significant source of $\mathrm{Ca}^{2+}$ in the groundwater and surface water sources arises from the exchange of ions between rocks and minerals in these areas, as suggested by (Roohul et al., 2012).

Further, the results may be an indication of the presence of $\mathrm{CaCO}_{3}, \mathrm{CaSO}_{4}, \mathrm{CaMg}\left(\mathrm{CO}_{3}\right)_{2}$ in the soil. Magnesium ion $\left(\mathrm{Mg}^{2+}\right)$ concentration $(\mathrm{mg} / \mathrm{L}$ ) is excessively found in surface $11.70 \pm 0.10$ (Majikuko) compared to underground samples of water from the areas of study ranging between $1.04 \pm 0.01$ (Kingwede) and $4.47 \pm 0.01$ (Fihoni). Table 4.7 shows that magnesium concentration in the three sample sites is within acceptable WHO standards of less than $300 \mathrm{ppm}$. The $\mathrm{Mg}^{2+}$ could perhaps have the same origin as $\mathrm{Ca}^{2+}$.

Sodium ions $\left(\mathrm{Na}^{+}\right)$concentration $(\mathrm{mg} / \mathrm{L})$ in-underground and surface water sources before filtration ranged from $11.33 \pm 1.53$ (Kingwede) to $64.20 \pm 0.20$ (Majikuko).

WHO (2017) stipulates the maximum permissible level should be at $200 \mathrm{mg} / \mathrm{L}$. Higher sodium ion $\left(\mathrm{Na}^{+}\right)$ concentration brings hypertension, congenital illnesses, kidney complications, and nervous disorders (Penerbit, 2014). The low $\mathrm{Na}^{+}$value in the underground and surface water is probably caused by the slow chemical breakdown of feldspars or under-utilization of the sub-surface sources. The findings are in line with (Harrison et al., 2016).

Potassium ions $\left(\mathrm{K}^{+}\right)$concentration in underground and groundwater sources varied between $1.17 \pm 0.06$ (Kingwede) and 55.33 \pm 0.60 (Majikuko) $\mathrm{mg} / \mathrm{L}$. Hydrogen carbonate $\left(\mathrm{HCO}_{3}{ }^{-}\right)$existed abundantly, and the level varied between $55.17 \pm 1.04$ to $225.67 \pm 0.58 \mathrm{mg} / \mathrm{L}$ from the sample of water fetched at Kingwede and Majikuko, respectively. The maximum allowable level for $\left(\mathrm{HCO}_{3}{ }^{-}\right)$is $300 \mathrm{mg} / \mathrm{L}$; thus, the sub-surface water from the study location is potable, as suggested by WHO (2017). The amount of $\mathrm{Cl}^{-}$in sub-surface and surface water varied from $10.00 \pm 1.00$ to $98.67 \pm 0.06 \mathrm{mg} / \mathrm{L}$. The acceptable level of $\mathrm{Cl}^{-}$for potable water is recommended to be $250 \mathrm{mg} / \mathrm{L}$ (Chen et al., 2017).

Chlorides are less harmful when they occur in small amounts, but at amounts exceeding $250 \mathrm{mg} / \mathrm{L}$, it tastes salty with some odour. They cause hypertension and trigger heart failure (Liu \& Dudley, 2020). The high amount of $\mathrm{Cl}^{-}$in ground and surface water sources is contributed by home effluents and infiltration in sub-surface soil layers in arid areas, as suggested by (Ponce 2014). It was also found that the amount of $\mathrm{SO}_{4}{ }^{2-}$ ions ranged from $2.76 \pm 0.01$ (Fihoni) to $28.60 \pm 0.01$ (Majikuko) $\mathrm{mg} / \mathrm{L}$. This was discovered to be below the maximum recommended level of $250 \mathrm{mg} / \mathrm{L}$ (WHO, 2017). Samples containing excessive amounts of $\mathrm{SO}_{4}{ }^{2-}$ in potable water cause breathing problems (Annapoorna \& Janardhana, 2015).

A T-test revealed significant variations in the chemical properties of water before and after filtration $(p<$ 0.001) (AF-After Filtration; BF-Before Filtration; LOD-Limit of Detection). The findings confirm the efficiency of the ceramic filter in filtering various minerals in the water. The results are supported by other similar studies such as (Ponce 2014). The levels of dissolved ions were reduced when the water samples were filtered through the activated carbon ceramic filter. 
3.4.1 Chemical Properties of the water samples in the study area

Table 3. 7: Descriptive results of chemical properties of the water Samples

\begin{tabular}{|c|c|c|c|c|c|c|c|c|c|}
\hline \multirow[t]{2}{*}{ Test Variable } & \multirow[t]{2}{*}{ Samples } & \multirow[t]{2}{*}{$\mathrm{N}$} & \multirow[t]{2}{*}{ Mean } & \multirow[t]{2}{*}{ Std. Dev } & \multirow[t]{2}{*}{ Std. Error } & \multicolumn{2}{|c|}{$95 \%$ confidence interval $(\mathrm{CI})$ for Mean } & \multirow[t]{2}{*}{ Min } & \multirow[t]{2}{*}{ Max } \\
\hline & & & & & & L.B & U. B & & \\
\hline \multirow[t]{3}{*}{$\mathrm{Ca}^{2+}$} & Unfiltered & 6 & 43.22 & 17.53 & 7.16 & 24.82 & 61.61 & 23 & 64.00 \\
\hline & Filtered & 6 & 4.05 & 2.02 & 0.82 & 1.93 & 6.17 & 1.54 & 6.50 \\
\hline & Total & 12 & 23.63 & 23.66 & 6.83 & 8.60 & 38.67 & 1.54 & 64.0 \\
\hline \multirow[t]{3}{*}{$\mathrm{Mg}^{2+}$} & Unfiltered & 6 & 5.99 & 5.10 & 2.08 & 0.63 & 11.34 & 1 & 12.80 \\
\hline & Filtered & 6 & 2.64 & 2.40 & 0.98 & 0.13 & 5.16 & 0 & 6.00 \\
\hline & Total & 12 & 4.32 & 4.18 & 1.21 & 1.66 & 6.97 & 0 & 12.80 \\
\hline \multirow[t]{3}{*}{$\mathrm{K}^{+}$} & Unfiltered & 6 & 22.25 & 28.06 & 11.46 & -7.20 & 51.7 & 1 & 61.52 \\
\hline & Filtered & 6 & 8.45 & 6.2 & 2.53 & 1.95 & 14.96 & 3 & 19.00 \\
\hline & Total & 12 & 15.35 & 20.67 & 5.97 & 2.22 & 28.49 & 1 & 61.52 \\
\hline \multirow[t]{3}{*}{$\mathrm{Na}^{+}$} & Unfiltered & 6 & 28.56 & 25.35 & 10.35 & 1.96 & 55.16 & 9.81 & 64.00 \\
\hline & Filtered & 6 & 12.80 & 12.23 & 4.99 & -0.03 & 25.63 & 1.98 & 30.00 \\
\hline & Total & 12 & 20.68 & 20.68 & 5.97 & 7.54 & 33.82 & 1.98 & 64.00 \\
\hline \multirow[t]{3}{*}{$\mathrm{Cl}^{-}$} & Unfiltered & 6 & 39.53 & 43.19 & 17.63 & -5.80 & 84.85 & 10 & 99.00 \\
\hline & Filtered & 6 & 23.20 & 28.11 & 11.47 & -6.30 & 52.7 & 3 & 64.00 \\
\hline & Total & 12 & 31.36 & 35.77 & 10.33 & 8.63 & 54.09 & 3 & 99.00 \\
\hline \multirow[t]{3}{*}{$\mathrm{SO}_{4}{ }^{2-}$} & Unfiltered & 6 & 13.70 & 13.12 & 5.36 & -0.07 & 27.46 & 3 & 31.89 \\
\hline & Filtered & 6 & 8.21 & 5.36 & 2.19 & 2.58 & 13.84 & 3 & 16.00 \\
\hline & Total & 12 & 10.95 & 9.98 & 2.88 & 4.61 & 17.29 & 3 & 31.89 \\
\hline
\end{tabular}

The analysis results revealed that the mean calcium cation was higher in the unfiltered underground and surface water than in the filtered underground and surface water $(43.22 \mathrm{v} 4.05)$. The results also indicated that the mean Magnesium cations exceeded unfiltered underground and groundwater contrary to filtered underground and surface water. This was denoted by the mean score of 5.99 and 2.64, respectively. Likewise, the mean potassium cations exceeded unfiltered underground and surface water contrary to the filtered underground and surface water $(28.06 \mathrm{v} 6.20)$. The findings show the role of ceramic water filters.

Further, the results indicated a higher mean sodium cation was in the unfiltered underground and surface water as compared to the filtered underground and surface water $(28.56 \mathrm{v} 12.80)$. The mean presence of chloride ions was also found to be higher in the unfiltered underground and surface water as compared to the filtered underground and surface water $(39.53 \mathrm{v} 23.20)$.

Also, sulfate presence in the underground and groundwater exceeded the unfiltered sub-surface and groundwater contrary to filtered underground and surface water (13.70 v 8.21). According to Penerbit (2014), the filters comprise tiny pores that prevent organic and inorganic particles (larger than 0.5 microns) from passing through. The results can, therefore, be explained in concurrence to the author. Water through ceramic filters has to pass through an intricate maze (Annapoorna \& Janardhana, 2015). The process explains why there was a variation between the filtered and unfiltered water samples.

3.4.2 Means of Chemical traits of Water Samples fetched from Majikuko, Kingwede, and Fihoni Areas The results showed a significant mean variation in calcium cations of the filtered and unfiltered underground and surface water $(0.000<0.05)$. The other cations, however, were found to be insignificant.

Table 3. 8: T-test of Chemical Properties of Water Samples from Majikuko, Kingwede, and Fihoni Area

\begin{tabular}{|llllllll|}
\hline Test Variable & Filtration & $\mathrm{N}$ & Mean & Std. Deviation & Std. Error Mean & $\mathrm{t}$ & Sig. (2-tailed) \\
\hline $\mathrm{Ca}^{2+}$ & Unfiltered & 6 & 43.22 & 17.532 & 7.157 & 5.436 & 0.000 \\
& Filtered & 6 & 4.05 & 2.018 & 0.824 & 5.436 & 0.003 \\
$\mathrm{Mg}^{2+}$ & Unfiltered & 6 & 5.99 & 5.102 & 2.083 & 1.453 & 0.177 \\
& Filtered & 6 & 2.64 & 2.398 & 0.979 & 1.453 & 0.189 \\
$\mathrm{~K}^{+}$ & Unfiltered & 6 & 22.25 & 28.063 & 11.457 & 1.176 & 0.267 \\
& Filtered & 6 & 8.45 & 6.196 & 2.53 & 1.176 & 0.288 \\
$\mathrm{Na}^{+}$ & Unfiltered & 6 & 28.56 & 25.348 & 10.348 & 1.371 & 0.200 \\
& Filtered & 6 & 12.8 & 12.229 & 4.992 & 1.371 & 0.211 \\
$\mathrm{Cl}^{-}$ & Unfiltered & 6 & 39.53 & 43.189 & 17.632 & 0.776 & 0.456 \\
& Filtered & 6 & 23.2 & 28.106 & 11.474 & 0.776 & 0.459 \\
$\mathrm{SO}_{4}{ }^{2-}$ & Unfiltered & 6 & 13.7 & 13.119 & 5.356 & 0.948 & 0.365 \\
& Filtered & 6 & 8.21 & 5.361 & 2.188 & 0.948 & 0.376 \\
\hline
\end{tabular}

The mean difference between the presence of magnesium cations, potassium cations, sodium cations, chlorides, and sulfate anions in the filtered and unfiltered underground and surface water were found to be statistically insignificant, i.e. $(0.177,0.267,0.200,0.456$ and 0.365 accordingly) as shown in the table 4.12 . The findings concurred with (Storti et al., 2017). According to the authors, ceramic filters tend to show considerable variation in calcium between filtered and unfiltered water. The differences occur because of the combination of chemicals occurring when water seeps through the ceramic pores. 


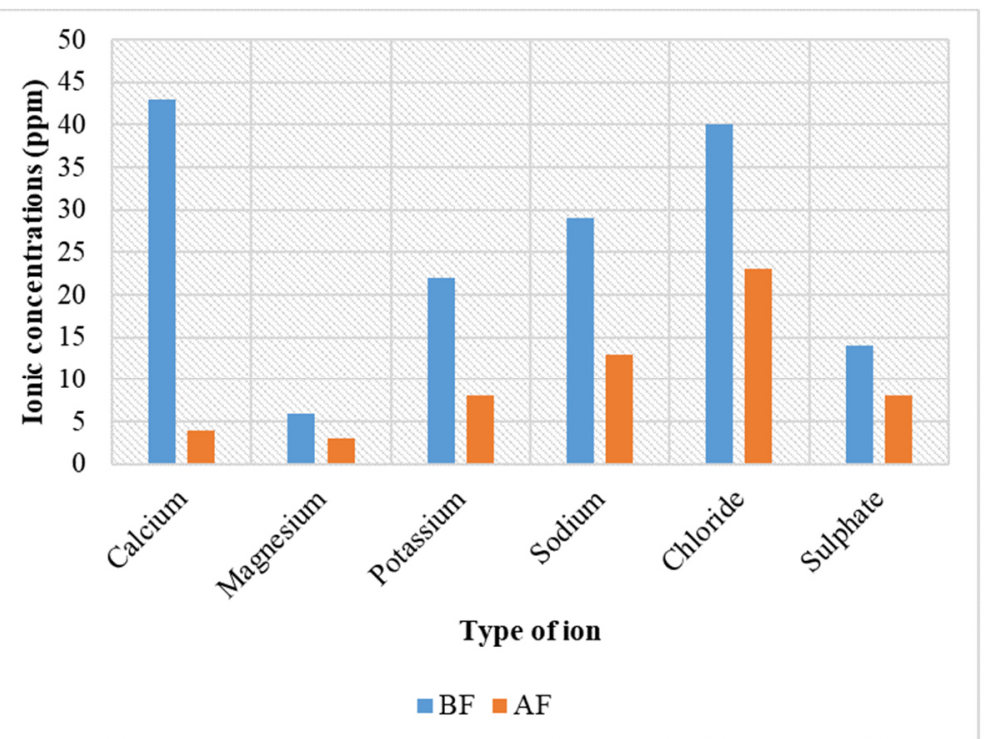

Figure 3. 9: Average levels of dissolved ions in water samples before and after filtration

The result of this study showed that ceramic filters had good removal efficiency of $\mathrm{Mg}^{2+}$ and $\mathrm{Ca}^{2+}$ that cause the hardness of water (figure 4.9). The removal of calcium and magnesium ions might be due to the ion exchange on the ceramic surface and precipitation formation as oxides and hydroxides of these cations. The central cations in clay structure, aluminium and silicon with higher charge might be replaced with a lower charge like magnesium and calcium by leaving a net negative charge.

The WHO guideline values are given for the concentration of calcium $75 \mathrm{mg} / \mathrm{L}$ and magnesium $30 \mathrm{mg} / \mathrm{L}$ in drinking water (WHO 2017).

\subsection{Hypothesis Testing}

Multiple linear regressions were applied in testing the hypotheses. Acceptance/rejection criteria were that if the $p$ value is below 0.05 , the $\mathrm{H} 1$ is not rejected, but if it's above 0.05 , the H1 fails to be accepted.

\subsubsection{Hypothesis Testing for Physico-Chemical Parameters}

From Table 4.3 above, the findings of the significance levels informed the hypothesis. The hypothesis was that there was no significant improvement of both chemical and physical parameters of drinking water when an activated carbon ceramic filter was used in water purification. Findings in Table 4.3 above showed the p-value for temperature to be $0.148>0.05$, $\mathrm{p}$-value for $\mathrm{pH}$ was $0.000<0.05$, $\mathrm{p}$-value for dissolved oxygen $0.000<0.05$, $\mathrm{p}$-value for electrical conductivity $0.186>0.05$ the $p$-value for salinity $0.204>0.05$ while the $p$-value for turbidity $0.004<0.05$.

The results indicated that the hypothesis for $\mathrm{pH}$, dissolved oxygen, and turbidity the alternative hypothesis upheld; hence there was a significant improvement in turbidity, dissolved oxygen, and $\mathrm{pH}$ of drinking water when an activated carbon ceramic filter was used in water purification. However, there was no significant improvement in temperature, electrical conductivity, and salinity of drinking water when an activated carbon ceramic filter was used in water purification.

\subsubsection{Hypothesis Testing for Bacteriological Water Contaminants}

The results in Table 4.6 showed the p values of faecal $E$. coli $(\mathrm{MPN})(\mathrm{CFU} / 100 \mathrm{ml})$ to be $(0.001<0.05)$ and Faecal coliforms $(\mathrm{MPN})(\mathrm{CFU} / 100 \mathrm{ml})(0.001<0.05)$ were statistically significant; hence the alternate hypothesis was upheld. Thus, there is a notable reduction of water contaminants in drinking water when an activated carbon ceramic filter is used in water purification.

\subsubsection{Hypothesis Testing for Water Dissolved Ions}

The findings in table 4.9 indicated that only calcium cations had a notable correlation with water filtration using an activated carbon ceramic filter. i.e. $0.000<0.05$. This indicated that the alternate hypothesis was upheld. Thus, there was a major improvement in calcium cations of drinking water when an activated carbon ceramic filter was used in water purification. However, there was no significant improvement of magnesium, potassium, sodium, chlorides, and bicarbonate and sulfate ions in drinking water when an activated carbon ceramic filter was used in water purification.

\section{Conclusion}

The water samples' physical properties (TDS, temperature, DO, turbidity, salinity, electrical conductivity (EC) and $\mathrm{pH}$ ) before and after filtration were determined. All the parameters ranged within the recommended limits set by 
(WHO 2004) guidelines for drinking water except turbidity $(30.00 \pm 1.00 \mathrm{NTU})$ and $\mathrm{DO} 2(4.21 \pm 0.96 \mathrm{mg} / \mathrm{L}) \mathrm{in}$ water samples obtained from Fihoni. These levels decreased significantly after filtration using the activated ceramic carbon filter with the water samples from Fihoni registering the lowest levels of $0.02 \pm 0.00 \mu \mathrm{S} / \mathrm{cm}$ for EC.

Total and Faecal coliforms were all above the permissible limits before filtration. The number of coliforms was almost constant at all sites; however, Majikuko and Kingwede recorded the highest number of faecal and total coliforms, respectively. The pathogenic bacterial isolated were Escherichia coli, Shigella spp, and Vibrio cholerae.

The levels $(\mathrm{mg} / \mathrm{L})$ of the mineral elements before filtration ranged from 1.04 \pm 0.01 in Kingwede for $\mathrm{Mg}^{2+}$ to $225.67 \pm 0.58$ for $\mathrm{HCO}_{3}{ }^{-}$in the water samples obtained from Majikuko. After filtration, these levels significantly decreased to $0.35 \pm 0.01$ for $\mathrm{Mg}^{2+}$ and $30.50 \pm 0.10$ for $\mathrm{HCO}_{3}{ }^{-}$in Fihoni and Majikuko water samples. These figures were within the WHO recommended limits.

The study shows that the majority of the parameters did not exceed the permissible limits of potable water. Some parameters were elevated in specific sampling sites, while for others, it was the reverse. The water samples in all the sampling sites were heavily polluted with coliforms. These levels significantly decreased after filtration using the activated carbon ceramic filter. Pollutant levels after filtration reported here were considerably lower than those in earlier studies of Diani and Mivumoni, respectively.

In Msambweni, the abstraction still seems not to have had an effect on the aquifer. There are no signs of seawater intrusion even when companies; like Base Titanium and KISCOL are abstracting more than $40,000 \mathrm{~m}^{3}$ per day. The findings indicate that the fabricated ceramic filter effectively reduces various physical and chemical parameters and bacteria that undermine the water quality.

\section{References}

Agustin, T. V. Y. (2016, September). Market Performance of High-Value Products of Coconut, The Philippine Experience. In Proceedings of the 47th APCC COCOTECH Conference (Vol. 2630).

Alemayehu, S. (2018). Low Cost And Efficient Removal Of Pathogenic Microbes And Fluorides Using Ceramic Water Filter (Doctoral dissertation, ASTU).

Aliyu, A., Usman, M., \& Audu, N. (2019). Development Of Ceramic Disc Water Filter For Domestic Use. Development.

Anastopoulos, I., Bhatnagar, A., Hameed, B. H., Ok, Y. S., \& Omirou, M. (2017). A review on waste-derived adsorbents from the sugar industry for pollutant removal in water and wastewater. Journal of Molecular Liquids, 240, 179-188.

Annapoorna, H., \& Janardhana, M. R. (2015). Assessment of groundwater quality for drinking purposes in rural areas surrounding a defunct copper mine. Aquatic Procedia, 4, 685-692.

Bhardwaj, R., Gupta, A., \& Garg, J. K. (2017). Evaluation of heavy metal contamination using environmetrics and indexing approach for River Yamuna, Delhi stretch, India. Water Science, 31(1), 52-66.

Bolisetty, S., Peydayesh, M., \& Mezzenga, R. (2019). Sustainable technologies for water purification from heavy metals: review and analysis. Chemical Society Reviews, 48(2), 463-487.

Bulta, A. L., \& Micheal, G. A. W. (2019). Evaluation of the efficiency of ceramic filters for water treatment in Kambata Tabaro zone, southern Ethiopia. Environmental Systems Research, 8(1), 1-15.

Chalala, A., \& Chimbevo, L. M. (2015). Effects of Sea Water Intrusion and Surface Water Salinity on Irrigation Water Quality in Ramisi. Published 2015, 69.

Chalala, A., Chimbevo, L. M., Kahindo, J. M., Awadh, M. M., \& Malala, J. B. (2017b). Seawater intrusion and surface water salinity and its influence on irrigation water quality in Ramisi area, Kenya. Journal of Agriculture and Ecology Research International, 1-13.

Chen, J., Wu, H., Qian, H., \& Gao, Y. (2017). Assessing nitrate and fluoride contaminants in drinking water and their health risk of rural residents living in a semiarid region of northwest China. Exposure and Health, 9(3), $183-195$

Coleman, B. L., Louie, M., Salvadori, M. I., McEwen, S. A., Neumann, N., Sibley, K., ... \& McGeer, A. J. (2013). Contamination of Canadian private drinking water sources with antimicrobial-resistant Escherichia coli. Water Research, 47(9), 3026-3036.

Corwin, D. L., \& Yemoto, K. (2020). Salinity: Electrical conductivity and total dissolved solids. Soil Science Society of America Journal, 84(5), 1442-1461.

Dai, Z., Zhang, H., Zhou, Q., Tian, Y., Chen, T., Tu, C., ... \& Luo, Y. (2018). Occurrence of microplastics in the water column and sediment in an inland sea affected by intensive anthropogenic activities. Environmental pollution, 242, 1557-1565.

Dong, X., Bäcker, L. E., Rahmatullah, M., Schunk, D., Lens, G., \& Meckenstock, R. U. (2019). Quantification of microbial degradation activities in biological activated carbon filters by reverse stable isotope labelling. AMB Express, 9(1), 1-7. https://doi.org/10.1186/s13568-019-0827-0

Dugdale, S. J., Hannah, D. M., \& Malcolm, I. A. (2017). River temperature modelling: A review of process-based approaches and future directions. Earth-Science Reviews, 175, 97-113. 
Farrow, C., McBean, E., Huang, G., Yang, A., Wu, Y., Liu, Z., ... \& Li, Y. (2018). Ceramic water filters: A pointof-use water treatment technology to remove bacteria from drinking water in Longhai City, Fujian Province, China. Journal of Environmental Informatics, 32(2), 63-68.

Ferrer Ramos, N. (2019). Assessment of a groundwater system under global change scenarios: the case of Kwale (Kenya).

Guo, A., Bowling, J. M., Bartram, J., \& Kayser, G. (2017). Water, Sanitation, and Hygiene in Rural Health-Care Facilities: A Cross-Sectional Study in Ethiopia, Kenya, Mozambique, Rwanda, Uganda, and Zambia. The American Journal of Tropical Medicine and Hygiene, 97(4), 1033-1042. https://doi.org/10.4269/ajtmh.170208

Hagemann, S., Chen, C., Clark, D. B., Folwell, S., Gosling, S. N., Haddeland, I., Hanasaki, N., Heinke, J., Ludwig, F., Voss, F., \& Wiltshire, A. J. (2013, May 1). Climate change impact on available water resources obtained using multiple global climate and hydrology models. Earth System Dynamics; Copernicus Publications. https://doi.org/10.5194/esd-4-129-2013

Harrison, A. D., Whale, T. F., Carpenter, M. A., Holden, M. A., Neve, L., O'Sullivan, D., ... \& Murray, B. J. (2016). Not all feldspars are equal: a survey of ice-nucleating properties across the feldspar group of minerals. Atmospheric Chemistry and Physics, 16(17), 10927-10940.

Haylamicheal, I. D., and Moges, A. (2012). Assessing water quality of rural water supply schemes as a measure of service delivery sustainability: A case study of WondoGenet district, Southern Ethiopia. African Journal of Environmental Science and Technology, 6(5), 229-236.

Hoekstra, A. Y., Mekonnen, M. M., Chapagain, A. K., Mathews, R. E., \& Richter, B. D. (2012). Global Monthly Water Scarcity: Blue Water Footprints versus Blue Water Availability. PloS One, 7(2), e32688-e32688. https://doi.org/10.1371/journal.pone.0032688

Kaurwar, A., Satankar, R., Gupta, S., Aravind, U. K., Kothari, K., Soboyejo, A., \& Plappally, A. (2017). Functional Demarcation of Traditional Off-White Colored Water Pots Manufactured from Rajasthan Clayey Soils and Red Colored Water Pots from Gujarat Clayey Soils Using Spectrographic, Cooling and Strength Studies--A Case Study from Jodhpur, Rajasthan, India. MRS Advances, 2(37), 2027-2032.

Kilwake, J. W. (2016). Assessment of Water Quality in Boreholes and Wells in Waa Location, Kwale CountyKenya [PhD Thesis]. Pwani University.

Lantagne, D., \& Yates, T. (2018). Household Water Treatment and Cholera Control. The Journal of Infectious Diseases, 218(suppl_3), S147-S153. https://doi.org/10.1093/infdis/jiy488

Lariyah, M. S., Mohiyaden, H. A., Hayder, G., Hussein, A., Basri, H., Sabri, A. F., \& Noh, M. N. (2016). Application of moving bed biofilm reactor (MBBR) and integrated fixed activated sludge (IFAS) for biological river water purification system: A short review. IOP Conference Series: Earth and Environmental Science, 32(1), 012005.

Mutuku, F. M., Khambira, M., Bisanzio, D., Mungai, P., Mwanzo, I., Muchiri, E. M., King, C. H., \& Kitron, U. (2013). Physical condition and maintenance of mosquito bed nets in Kwale County, coastal Kenya. Malaria Journal, 12(1), 46. https://doi.org/10.1186/1475-2875-12-46

Mwihaki, N. J. (2018). Decentralisation as a tool in improving water governance in Kenya. Water Policy, 20(2), 252-265. https://doi.org/10.2166/wp.2018.102

Nichols, B. D. (2016). Materials for manufacturing low-tech, low-cost ceramic water filters and the business models for their distribution in Central America (Doctoral dissertation, University of British Columbia).

Nnaji, C. C., Afangideh, B. C., \& Ezeh, C. (2016). Performance evaluation of clay-sawdust composite filter for point of use water treatment. Nigerian Journal of Technology, 35(4), 949-956.

O'Connor, D., Hou, D., Ok, Y. S., Song, Y., Sarmah, A. K., Li, X., \& Tack, F. M. (2018). Sustainable in situ remediations of recalcitrant organic pollutants in groundwater with controlled-release materials: A review. Journal of Controlled Release, 283, 200-213.

Olago, D. O. (2018). Constraints and solutions for groundwater development, supply and governance in urban areas in Kenya. Hydrogeology Journal, 27(3), 1031-1050. https://doi.org/10.1007/s10040-018-1895-y

Onyuka, J. H., Kakai, R., Onyango, D. M., Arama, P. F., \& Gichuki, J. (2011). Prevalence and Antimicrobial Susceptibility Patterns of Enteric Bacteria Isolated from Water and Fish in Lake Victoria Basin of Western.

Penerbit, U. M. T. (2014). Initial Study On Bacterial Count For Two Beaches In Peninsular Malaysia. Journal of Sustainability Science and Management, 9(2), 109-113.

Peralta, N. R., \& Costa, J. L. (2013). Delineation of management zones with soil apparent electrical conductivity to improve nutrient management. Computers and electronics in agriculture, 99, 218-226.

Petrova, M. I., Lievens, E., Malik, S., Imholz, N., \& Lebeer, S. (2015). Lactobacillus species as biomarkers and agents that can promote various aspects of vaginal health. Frontiers in physiology, 6, 81 .

Ponce, V. M. (2014). Total dissolved solids (TDS) based on electrical conductivity (EC). Online Salinity Calculator. 
Ponce-Robles, L., Ponce-Robles, L., Miralles-Cuevas, S., Miralles-Cuevas, S., Oller, I., Oller, I., Agüera, A., Agüera, A., Trinidad-Lozano, M. J., Trinidad-Lozano, M. J., Yuste, F. J., Yuste, F. J., Malato, S., \& Malato, S. (2017). Cork boiling wastewater treatment and reuse through the combination of advanced oxidation technologies. Environmental Science and Pollution Research International, 24(7), 6317-6328. https://doi.org/10.1007/s11356-016-7274-0

Roche, R., Bain, R., \& Cumming, O. (2017). A long way to go - Estimates of combined water, sanitation and hygiene coverage for 25 sub-Saharan African countries. PloS One, 12(2), e0171783-e0171783. https://doi.org/10.1371/journal.pone.0171783

Rojas, A., Murphy, S. I., Wiedmann, M., \& Martin, N. H. (2020). Coliform Petrifilm as an alternative method for detecting total gram-negative bacteria in fluid milk. Journal of dairy science, 103(6), 5043-5046.

Roohul, A., Syed, S.A., Zubair, A., and Jabar, Z K.K. (2012). Microbial analysis of drinking water and water distribution system in new urban Peshawar. Current Research Journal of Biological Science, 4: 731-737

Sila, O. N. A. (2019). Physico-chemical and bacteriological quality of water sources in rural settings, a case study of Kenya, Africa. Scientific African, 2, e00018.

Storti, E., Farhani, M., Aneziris, C. G., Wöhrmeyer, C., \& Parr, C. (2017). Calcium Aluminate Reactive Coatings on Carbon - Bonded Alumina Filters for Clean Steel Approaches. steel research international, 88(11), 1700247.

Teshome, F. B. (2020). Seasonal water quality index and suitability of the water body to designated uses at the eastern catchment of Lake Hawassa. Environmental Science and Pollution Research, 27(1), 279-290.

Uhuo, C. A., Uneke, B. I., Okereke, C. N., Nwele, D. E., \& Ogbanshi, M. E. (2014). The bacteriological survey of borehole waters in Peri-Urban areas of Abakaliki; Ebonyi State, Nigeria. International Journal of Bacteriology Research, 2(2), 028-031.

World Health Organization. (2017). Water quality and health-review of turbidity: information for regulators and water suppliers.

Zaman, S., Begum, A., Rabbani, K. S., \& Bari, L. (2017). Low cost and sustainable surface water purification methods using Moringa seeds and scallop powder followed by bio-sand filtration. Water Science \& Technology. Water Supply, 17(1), 125-137. https://doi.org/10.2166/ws.2016.111

Zereffa, E. A., \& Bekalo, T. B. (2017). Clay ceramic filter for water treatment. Materials Science and Applied Chemistry, 34(1), 69-74. 